\title{
From Lab to Farm: Elucidating the Beneficial Roles of Photosynthetic Bacteria in Sustainable Agriculture
}

\author{
Sook-Kuan Lee ${ }^{1}$, Huu-Sheng Lur ${ }^{2}$ and Chi-Te Liu ${ }^{1,3,4, *}$ \\ 1 Institute of Biotechnology, National Taiwan University, R412, No.81, Chang-Xing St, Taipei 106, Taiwan; \\ D06642002@ntu.edu.tw \\ 2 Department of Agronomy, National Taiwan University, No.1, Sec. 4, Roosevelt Road, Taipei 106, Taiwan; \\ lurhs@ntu.edu.tw \\ 3 Agricultural Biotechnology Research Center, Academia Sinica, No.128, Sec. 2, Academia Road, Nankang, \\ Taipei 115, Taiwan \\ 4 Department of Agricultural Chemistry, National Taiwan University, No.1, Sec. 4, Roosevelt Road, \\ Taipei 106, Taiwan \\ * Correspondence: chiteliu@ntu.edu.tw; Tel.: +886-2-3366-6025
}

Citation: Lee, S.-K.; Lur, H.-S.; Liu, C.-T. From Lab to Farm: Elucidating the Beneficial Roles of Photosynthetic Bacteria in Sustainable Agriculture. Microorganisms 2021, 9, 2453. https://doi.org/10.3390/ microorganisms 9122453

Academic Editor: Hitoshi Miyasaka

Received: 22 October 2021

Accepted: 24 November 2021

Published: 28 November 2021

Publisher's Note: MDPI stays neutral with regard to jurisdictional claims in published maps and institutional affiliations.

Copyright: (c) 2021 by the authors. Licensee MDPI, Basel, Switzerland. This article is an open access article distributed under the terms and conditions of the Creative Commons Attribution (CC BY) license (https:// creativecommons.org/licenses/by/ $4.0 /)$.
Abstract: Photosynthetic bacteria (PSB) possess versatile metabolic abilities and are widely applied in environmental bioremediation, bioenergy production and agriculture. In this review, we summarize examples of purple non-sulfur bacteria (PNSB) through biofertilization, biostimulation and biocontrol mechanisms to promote plant growth. They include improvement of nutrient acquisition, production of phytohormones, induction of immune system responses, interaction with resident microbial community. It has also been reported that PNSB can produce an endogenous 5-aminolevulinic acid (5-ALA) to alleviate abiotic stress in plants. Under biotic stress, these bacteria can trigger induced systemic resistance (ISR) of plants against pathogens. The nutrient elements in soil are significantly increased by PNSB inoculation, thus improving fertility. We share experiences of researching and developing an elite PNSB inoculant (Rhodopseudomonas palustris PS3), including strategies for screening and verifying beneficial bacteria as well as the establishment of optimal fermentation and formulation processes for commercialization. The effectiveness of PS3 inoculants for various crops under field conditions, including conventional and organic farming, is presented. We also discuss the underlying plant growth-promoting mechanisms of this bacterium from both microbial and plant viewpoints. This review improves our understanding of the application of PNSB in sustainable crop production and could inspire the development of diverse inoculants to overcome the changes in agricultural environments created by climate change.

Keywords: phototrophic bacteria; plant growth promoting rhizobacteria (PGPR); biotic and abiotic stress; sustainable agriculture; secondary metabolite; biofertilizer; biostimulant; food crops

\section{Introduction}

In the 20th century, the emergence of the green revolution triggered a worldwide boom in the agriculture industry [1]. To feed the global population, this revolution contributed significantly to improving the productivity of crops by increasing the use of chemical fertilizers, pesticides and other agrochemicals [2]. However, the amount of arable land has drastically decreased since the start of the green revolution [3]. The overuse of synthetic agrochemicals to enhance crop yields acidifies soils, decreases fertility, destroys food web systems, pollutes air and water and releases greenhouse gases, thereby posing hazards to human health and environments [1,4-8]. By 2050, the world population is estimated to reach 9.8 billion, which has been estimated as Earth's maximum capacity [9]. The combination of all these problems and challenges poses a serious threat to global food security and the stability of economies [10].

The pursuit of quality, fresh, nontoxic and safe products has become the trend of global agricultural production. To mitigate the overuse of synthetic agrochemicals and 
soil biodiversity loss, various beneficial microbes have been used to date as biofertilizers and biopesticides for sustainable agricultural farming [11,12]. Kloepper and colleagues first proposed the concept of plant growth-promoting rhizobacteria (PGPR), indicating that beneficial soil bacteria colonize the rhizosphere [13]. Currently, dozens of species and many hundreds of potential microbial strains of PGPR have been screened and evaluated under laboratory, greenhouse and field conditions [14]. These PGPR include diverse genera of bacteria, such as Rhizobium, Pseudomonas, Azospirillum, Azotobacter and Bacillus [15,16]. PGPR inoculants can fertilize several important agronomic plants, such as rice, maize, potato, bean, strawberry, cucumber and tomato [17-22]. PGPR stimulate plant growth through nutrient acquisition, biological nitrogen fixation (BNF), phytohormone production, disease control through antagonism, induced systemic resistance (ISR) or volatile organic compounds (VOCs) [13,23-26].

Photosynthetic bacteria (PSB), including oxygenic and anoxygenic phototrophic bacteria, are prokaryotes that are capable of carrying out photosynthesis [27]. Oxygenic photosynthesis is limited to cyanobacteria, whereas anoxygenic phototrophs are widely distributed among bacterial taxa. In this review, we focused on the application of anoxygenic PSB in agriculture. These bacteria can grow in either aerobic or anaerobic conditions and can use either organic or inorganic substances as electron donors to fix $\mathrm{N}_{2}$ and $\mathrm{CO}_{2}$ [28-30]. Among anoxygenic PSB, purple non-sulfur bacteria (PNSB) are a major group, containing Rhodopseudomonas spp., Rhodobacter spp. and Rubrivivax spp. [31]. They are widely distributed in natural environments, such as lakes, lagoons, wastewater ponds, sediment, moist soils, wetland ecosystems, marine environments and hypersaline systems [32-34]. Since PNSB possess versatile metabolic pathways, they are attractive candidates for multiple industrial applications. For example, they are broadly applied in the fisheries industry [35] and livestock industry, in bioremediation for sewage and heavy metals [36,37] and in the production of biofuels (photohydrogen or electricity) [38,39].

In addition to environmental applications, many studies have reported that PNSB can be applied directly to soil or plants to improve soil fertility and crop yield. In the first part of this review, we introduce the concept and roles of beneficial PNSB inoculants in agriculture. In the second part, the deduced mechanisms of plant growth promotion by PNSB are discussed, including the influence of PNSB on plant health and soil microbial community. In the third part, we emphasize the influence of Rhodopseudomonas spp. on crop production and share experiences gained while researching and designing an elite phototrophic bacterium, Rhodopseudomonas palustris PS3, in our lab. Overall, the information generated from this review could be very beneficial to those who are concerned about environmental protection and agricultural sustainability.

\section{Plant Growth Promoting (PGP) Traits Exerted by PNSB on Crops}

Previously, Sakarika and colleagues made a comprehensive survey in respect to the potential of using PNSB in plant production [40]. We further updated the latest studies published within these two years and summarized them in Supplementary Table S1. As shown, PNSB microbial inoculants could not only increase the yield and quality of edible plant biomass, but also alleviate the biotic and abiotic stress in crops and mitigate environmental stress. It has been demonstrated that the addition of PNSB by foliar spray or soil application significantly improves the growth responses of leafy crops, such as pak choi (B. chinensis L.), mustard spinach, sugar leaf, spinach and lettuce [41-48]. Similarly, the use of Rhodobacter sphaeroides NR3 enhanced the carotenoid content of spinach (14-138\%) and mustard spinach (4.1-21\%) [44]. The nitrogen content of rice grains increased by $7.1 \%$ after inoculation with Rhodobacter capsulatus DSM 155 [49,50]. In comparison with uninoculated treatment, R. sphaeroides KE149 inoculation markedly improved cucumber morphological characteristics by up to two times through IAA and organic acid production [51]. Finally, inoculation with $R$. palustris PS3 reduced the nitrate content of the nitrate-rich vegetables pak choi (20-50\%) and lettuce (27\%) [41]. This could have a positive effect on high-nitrate 
diets (e.g., Mediterranean or Japanese diets), since high dietary nitrate intake is often associated with health risks [52].

In addition to increasing the quantity and quality of leafy vegetables, inoculation with PNSB also exerts positive effects on fruits. For example, Lee (2009) reported that inoculation with Rhodopseudomonas sp. BL6 and KL9 resulted in the stimulation of metabolic activity and an increase in fruit weight, fruit formation and lycopene contents of tomato plants $[53,54]$. Kondo's research group reported that the application of $R$. sphaeroides enhanced the quality of tomato plants, e.g., by increasing the Brix sugar content and ascorbic acid, carotenoid and citric acid contents, although the yield was not increased accordingly [55]. It has also been reported that inoculation of PSB on citrus fruit resulted in an improvement of the taste as well as an increase in the sugar and carotenoid contents (by $5.8 \%$ and $20 \%$, respectively) [56]. Li's research group applied a foliar spray of PNSB on melon seedlings and found that the levels of some biochemical substances, such as sucrose, soluble sugar and proline, were increased by up to $40 \%$ [57]. In addition, the biomass of PNSB-treated melon seedlings was significantly increased even under low temperatures [57]. Foliar spraying of PNSB under low temperatures also improved the chlorophyll content, photosynthetic rate and protective enzyme activity in yellow-skinned watermelon [58]. Stevia, with the common name sweet leaf or sugar leaf, is a plant that serves as a natural sweetener. Treating stevia with Rhodopseudomonas sp. ISP-1 by foliar spray or soil irrigation resulted in a $77-116 \%$ increase in soluble sugars and a $69 \%$ increase in stevioside content [46,47]. Moreover, it has also been reported that foliar inoculation with ISP-1 may have improved net photosynthesis and plant biomass in pot experiments.

Asian rice (Oryza sativa L.), which is a staple for over half of the global population, is cultivated universally [59]. In an early study, treating PNSB inoculants at the reproductive stage with $\mathrm{N}$ fertilizer in the form of ammonia chloride was shown to increase the grain yield of rice by $32 \%$ [60]. R. capsulatus DSM155 was initially isolated from a sewage processing plant [61]. When rice was inoculated with this bacterium through a hydroponic system, there was a $9-53 \%$ improvement in the aerial biomass compared to that of rice in a control treatment without inoculation [61]. Harada and colleagues reported that the R. palustris strain KN122 isolated from paddy soil was able to utilize rice straw as a nutrient for growth [62]. Triplicate treatments of soil and rice straw with this bacterium (dosage concentrations of approximately $5.1 \times 10^{9}$ to $1.7 \times 10^{11} \mathrm{MPN} /$ pot) increased grain yields by up to $29 \%$ [62]. PNSB was also reported to increase panicle formation and plant nitrogen content. Yoshida and colleagues reported that treating rice seedlings with a PNSB inoculant three weeks before the heading stage increased the grain yield and panicle number by $200 \%$ compared to that in treatments without PNSB inoculation [63]. It has also been reported that inoculating rice with $R$. capsulatus could increase the nitrogen contents in straw and grain and the biological and grain yields of inoculated plants have been shown to be higher than those of plants without inoculation [64]. Sakpirom and colleagues reported that treating rice seedlings with the formulated $R$. palustris TN110, Ru. gelatinosus TN414 or mixed inoculants significantly increased the weight and length [65].

Inoculation of PNSB also has great potential to alleviate many of the abiotic stresses related to climate change in plants, such as salt stress and contamination of heavy metals $[66,67]$. For example, Ge and colleagues reported that treating cucumber seedlings with R. palustris strain G5 (isolated from the mud and water of the Qingshui River in Zhoukou city, Henan Province, China) could not only reduce the damage caused by cadmium and salt stress but also enhance the agronomic traits and activities of reactive oxygen species of the plants [68,69]. R. palustris CS2 and R. faecalis SS5 were both isolated from fish ponds in Pakistan [70]. It has been reported that these strains can detoxify arsenic (As) contamination and support seedling growth of Vigna mungo. R. palustris C1 was isolated from an As-contaminated paddy field near mines in Thailand [71]. This bacterium was reported to ameliorate As toxicity and reduce As uptake in rice. On the other hand, mixing R. palustris C1 and another PNSB strain, Ru. benzoatilyticus C31, was shown to potentially enhance the growth of two rice cultivars under As stress [72]. It has been suggested 
that the beneficial effects of these strains were due to the increase in the production of chlorophyll $a$ and $b$ resulting from the mixed culture as well as the increase in the activities of nonenzymatic (carotenoids, lipid oxidation-related and nitric oxide) and antioxidant (superoxide dismutase, ascorbate peroxidase, catalase and glutathione reductase) enzymes in rice $[70,72]$.

Studies have indicated that PNSB play a role in plant disease control by mitigating biotic stresses. Su and colleagues reported that preinoculation of R. palustris GJ-22 (isolated from activated sludge) on tobacco could elevate plant immunity during subsequent tobacco mosaic virus (TMV) infection and reduce the infection rate of TMV on leaves [73-75]. R. palustris KTSSR54 (isolated from Kan-Tulee peat swamp forest, Thachana district, Surat-Thani Province, Thailand) was shown to protect rice from infection by fungal pathogens, particularly those cultivated in acidic soils [76,77]. Recently, a IAA-producing rhizobacterium $R$. sphaeroides KE149 was reported to be able to improve adzuki bean's morphological characteristics as well as to regulate phytohormone content under flood and drought stress [78]. In addition, co-inoculation with KE149 and biochar could help to promote plant growth and strengthen the antioxidant system of soybean plant while grown under normal and stress conditions [79].

\section{Deduced PGP Mechanisms of PNSB}

It has been reported that PGPR improve plant growth by facilitating nutrient acquisition and phytohormone production or inducing the immune system in plants [80]. Sakarika and colleagues have summarized three key performance indicators (KPIs) of PNSB for plant production, including direct and indirect fertilization as well as biostimulation and biofortification [40]. In this review, we further proposed the PGP mechanisms of PNSB from both microbial and plant viewpoints based on the latest research findings. As illustrated in Figure 1, PNSB mainly use biofertilization, biostimulation or biocontrol to promote plant growth.

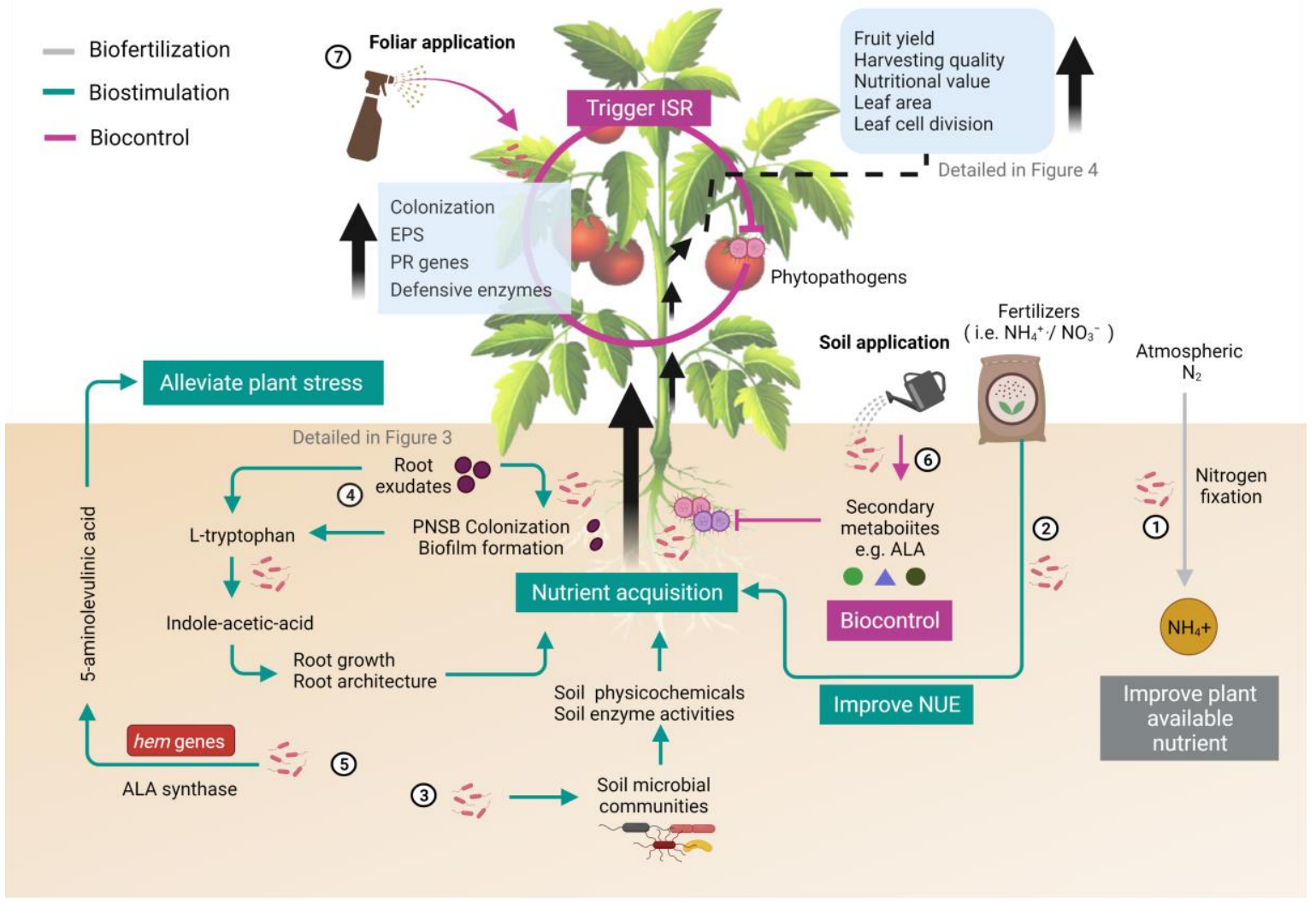

Figure 1. Major mechanisms by which inoculation with purple non-sulfur bacteria (PNSB) benefit the growth and quality of plants. Biofertilization (grey), biostimulation (green) and biocontrol (magenta) are three modes of action exerted by PNSB 
to promote plant growth and quality. The numbers marked in the illustration represent the beneficial effects exerted by PNSB, which were explained below. (1) Plant-available nutrients in soil are enhanced through biological nitrogen fixation (BNF) by free-living PNSB (biofertilization). (2) PNSB improve the nitrogen use efficiency (NUE) of host plants and stimulate plants to uptake more nitrate from soil (biostimulation). (3) PNSB interact with resident microbial community to improve soil health, thus, increase nutrient acquisition (biostimulation). (4) Indole-acetic acid (IAA) is synthesized by PNSB to promote growth and improve nutrient acquisition/absorption in roots (biostimulation). (5) 5-Aminolevulinic acid (ALA) produced by PNSB through the involvement of ALA synthase and hem genes to alleviate abiotic stress (biostimulation). (6) Secondary metabolites (e.g., 5-ALA) are synthesized to suppress soil pathogens directly (biocontrol). (7) Exopolysaccharides (EPSs) are produced by PNSB and pathogenesis-related (PR) genes of plants are upregulated to trigger an induced systemic response (ISR) to control plant pathogens (biocontrol). This illustration was created at BioRender.com (accessed on 20 November 2021) and the tomato image was attributed by blueringmedia (accessed on 20 November 2021).

\subsection{PNSB as Biofertilizers to Increase Plant-Available Nutrients in Soil}

Nitrogen is the most abundant element in our planet's atmosphere and is a crucially important component for all life [81]. Two of the major components of plants are chlorophyll, the most important pigment for photosynthesis and amino acids, the key building blocks of proteins $[82,83]$. However, atmospheric nitrogen $\left(\mathrm{N}_{2}\right)$ in gaseous form cannot be utilized by living organisms. It has to be transformed into an available form through a process called fixation. The process of converting atmospheric nitrogen to plant-available nitrogen, that is, biological nitrogen fixation (BNF), is carried out by nitrogen-fixing bacteria [84,85]. These nitrogen-fixing bacteria are either free-living or symbiotic diazotrophs [86]. PNSB belong to free-living diazotrophs. In general, free-living nitrogen-fixing bacteria do not penetrate root tissues; instead, fixed nitrogen is taken up by associated plants, allowing better nitrogen absorption [87]. PNSB transform atmospheric molecular nitrogen into ammonia $\left(\mathrm{NH}_{3}\right)$ or ammonium $\left(\mathrm{NH}_{4}{ }^{+}\right)$with a specific nitrogenase enzyme, thus making nitrogen available for plant absorption [84,88]. Since biofertilizers are living microbes that can enhance plant nutrition by mobilizing or increasing nutrient availability, PNSB can be categorized among them. Previously, nitrogen fixing ability was determined by Nessler's reagent and a nitrogen-free medium without nitrogenase cofactors [65]. Sakpirom and colleagues reported that the elite R. palustris strain TN110 encoded three sets of Mo, V and $\mathrm{Fe}$ nitrogenase gene clusters, which resulted in the release of higher concentrations of $\mathrm{NH}_{4}{ }^{+}$than other tested strains [65]. On the other hand, although the elite R. palustris strain PS3 could fix N under light-microaerobic condition, only anf (encoding iron nitrogenase) and nif (encoding molybdenum nitrogenase) nitrogenase-related genes and no vnf-related gene were found in its genome [89].

\subsection{PNSB as Plant Biostimulants or Growth Regulators}

Plant biostimulants (PBs) are a new category of crop inputs, which have been attracted broad attention for the past decade. They are recently under the new Regulation (EU) 2019/1009, which led to the following: "A plant biostimulant shall be an EU fertilizing product the function of which is to stimulate plant nutrition processes independently of the product's nutrient content with the sole aim of improving one or more of the following characteristics of the plant or the plant rhizosphere: (i) nutrient use efficiency, (ii) tolerance to abiotic stress, (iii) quality traits, or (iv) availability of confined nutrients in the soil or rhizosphere" (EU, 2019). Some PNSB inoculants functions in accordance with these criteria are described below.

\subsubsection{Indole-3-Acetic Acid (IAA) Production by PNSB}

Phytohormones are key participants in regulating plant growth and development $[90,91]$. Many beneficial soil bacteria are known to secrete phytohormones for root uptake or to regulate hormone balances in crops, thus enhancing growth and abiotic responses [92].

Because they control assorted stages of plant growth and development, auxins play key roles in regulating processes of the plant life cycle, such as cell division, cell elongation, tissue differentiation and apical dominance $[87,93]$. Indole-3-acetic acid (IAA) is the 
most widely studied auxin produced by PGPR [1] The IAA produced by PGPR stimulates seed germination and root development; enhances vegetative growth and fructification; improves photosynthetic and biosynthetic abilities, such as the production of pigments and metabolites; elicits transcriptional differences in hormone-, defense- and cell wallrelated genes; and is responsible for alleviating the abiotic stress of plants, such as that due to drought and saline [91,93-96]. Biosynthesis of IAA in microorganisms occurs via tryptophan-dependent and the tryptophan-independent pathways [97,98]. In general, PNSB can produce IAA through indole-3-pyruvate (IPA) and tryptamine (TAM) pathways, which use tryptophan as a precursor molecule [54,99]. However, there are few studies on the tryptophan-independent pathway in bacteria [98]. Mariana and colleagues suggested that the tryptophan-independent pathway is made up of three stages [100]: from chorismic acid (CHA) to anthranilic acid (AA), from AA to IAA and from tryptophan (TRP) to AA through kynurenine (KYN). For the elite R. palustris PS3 strain described above, IAA $\left(140 \mu \mathrm{M} / \mathrm{OD}_{530}\right)$ can be produced in the presence of tryptophan and synthesized via an unidentified pathway with some genes, such as $\operatorname{trp} B A$ and $\operatorname{tna} A$ genes, which were involved in the IAA synthesis [89]. Sakpirom and colleagues found that $R$. palustris TN110 and Rubrivivax gelatinosus TN41 could produce $0.65-3.6 \mathrm{mg} / \mathrm{L}$ IAA under facultative aerobic conditions [65]. Two other R. palustris strains, GJ-22 and KL9, have also been reported to yield 30-52 mg/L IAA in the presence of tryptophan [73,101]. It was reported that $R$. palustris KKSSR91, which secreted IAA $(29.58 \mathrm{mg} / \mathrm{L})$ in the presence of $3 \mathrm{mM}$ tryptophan, was able to reduce the phytotoxic effects of acid on kidney bean plants [102]. Rhodobacter capsulatus PS-2, which was isolated from paddy soil, was capable of producing a large amount of IAA $(197.44 \pm 5.92 \mathrm{mg} / \mathrm{L})$ in an optimal medium containing 0.3\% tryptophan. [103]. Recently, Kang and colleagues also reported that $R$. sphaeroides KE149 could produce $4.6-5.3 \mu \mathrm{g} / \mathrm{mL}$ of IAA in the presence of D-tryptophan in medium and was able to alleviate the adverse effect of water stress for adzuki bean plants [78].

\subsubsection{PNSB Improve Nitrogen Use Efficiency by Interaction with Plants}

Nitrogen use efficiency (NUE) reflects the potential ability of plants to consume and utilize nitrogen for maximum yields [104]. NUE is associated with both $\mathrm{N}$ uptake efficiency (NupE) and N utilization or assimilation efficiency [104-106]. Increasing NUE is critical to improve crop yield, reduce $\mathrm{N}$ fertilizer demand and alleviate environmental pollution. PNSB has been reported to improve the NUE of plants [41,42,45]. Elbadry and Elbanna found that inoculating rice with $R$. capsulatus DSM155 in the presence of $\mathrm{N}$ fertilizer could increase the nitrogen content in roots by $20 \%$. However, the effect of inoculation was lower in the presence of $\mathrm{N}$ fertilizer than in $\mathrm{N}$-deficient conditions [61]. In addition, inoculation with DSM155 caused a 2.5-fold increase in N contents in roots under $\mathrm{N}$-deficient conditions [61]. Thus, these results suggested that $R$. capsulatus DSM155 could not only supply the host plants with fixed nitrogen in the absence of $\mathrm{N}$ fertilizer but also improve the NUE in the presence of $\mathrm{N}$ fertilizer [61].

Excessive application of nitrogen fertilizer is considered the major cause of nitrate accumulation in plants [107]. In particular, leafy vegetables tend to accumulate nitrate under low light conditions, as the uptake of nitrate exceeds the rate of nitrate reduction [108]. High nitrate contents in vegetables potentially increase the risk of human illnesses, such as gastric cancer, esophageal cancer and methemoglobinemia [109]. Wong and colleagues reported that the nitrate contents in the leaves of Chinese cabbage were significantly lower in plants in which the roots were inoculated with $R$. palustris PS3 than in plants that were not inoculated [45]. Furthermore, Hsu and colleagues demonstrated that the NUE of plants was remarkably increased in the presence of PS3 inoculation, allowing nitrate to be effectively catabolized [42].

\subsubsection{5-ALA of PNSB Can Alleviate Abiotic Stress of Plants}

Drought, salinity and extreme temperature were thought to contribute to $70 \%$ of yield gap dictated by global climatic change [110]. Given the current climate change scenario, 
abiotic stresses are likely to pose a serious threat to crop productivity and, thus, global food security [111]. In order to address this situation, the application of plant biostimulants has been proposed as one of the most promising and efficient strategies for improving yield stability [112].

5-Aminolevulinic acid (5-ALA), which is abundant in bacteria, algae, plants and animals, is an intermediate compound involved in tetrapyrrole biosynthesis of compounds such as porphyrin, heme, chlorophyll and vitamin B12 [113]. 5-ALA is also considered a plant growth regulator, participates in the enhancement of plant growth and yield and confers tolerance to plants of various abiotic stresses [46]. Exogenous 5-ALA has been reported to increase crop yields by regulating the chlorophyll biosynthesis and photosynthesis systems [114,115]. However, the underlying mechanisms through which 5-ALA regulation of plant growth have not been fully elucidated. The use of PNSB has been reported to be an effective approach for ALA production [116]. Many PNSBs, such as $R$. palustris, $R$. sphaeroides and Rhodovulum sp., have been identified as potential 5-ALA producers [65,117-119]. According to the results of comparative genomics, the genes hemO and hemA of $R$. palustris are associated with the biosynthesis of 5-ALA [89]. Nunkaew and colleagues reported that the application of $R$. palustris TN114 supernatant ameliorated rice seedling growth under $\mathrm{NaCl}$ stress and the effect was comparable to that of commercial 5-ALA [118]. 5-ALA can also be used as a safe and biodegradable herbicide [120,121].

\subsubsection{PNSB Interaction with Microbial Communities to Improve Soil Health and Crop Quality}

Soil health refers to the ecological equilibrium and functionality of soil, indicating the ability to sustain agricultural productivity and protect environmental resources [122]. In general, healthy soils contain favorable biological, physical and chemical properties for producing healthy crops $[94,123]$. The indicators for evaluating soil health include those of soil microbial communities and physiochemical and enzyme activities [122,124,125]. Beneficial rhizosphere microbes play vital roles in organic matter decomposition and nutrient cycling of carbon, nitrogen and phosphorus; these processes may represent a correlation between plant and soil functions [126,127]. Generally, soil enzyme activities directly reflect the metabolic requirements and available nutrients of soil microorganisms [128]. As mentioned, the structures of soil microbial communities can be influenced by the physical and chemical properties of the soil as well as by exotic microbial inoculants [129-131]. Microbial inoculants must sustain their populations and interact with indigenous microbes in soil to enhance plant growth [132]. Xu and colleagues found that inoculating stevia (i.e., sugar leaf) in continuously fertilized soil with $R$. palustris elevated the soil dehydrogenase and urease activities to a remarkable extent [47]. Moreover, the abundances of some bacterial lineages in the soil increased. It has been indicated that continuous use of chemical fertilizers has strong negative effects on soil microbial community properties, especially on dehydrogenase and urease activities [133]. Therefore, $R$. palustris inoculation can improve soil health by reducing the negative impacts of continuous chemical fertilization on the microbial community [47]. This research group also reported that treating Chinese pak choi with $R$. palustris can enhance soil microbial metabolic activity and alter the abundances of some bacterial groups $[47,48]$. They found that the abundances of the operational taxonomic units (OTUs) related to the acceleration of carbon and nutrient cycling in soil, such as those phyla belonging to the Proteobacteria, Planctomycetes, Acidobacteria, Actinobacteria, Verrucomicrobia and Nitrospirae, were significantly increased following treatment with $R$. palustris. Lee's group reported that the application of PNSB improved the fresh weights and lycopene contents of tomatoes; however, the bacterial communities in the rhizosphere were not altered [53]. Wang and colleagues reported that inoculating peanut with a mixed bacterial inoculant containing $R$. palustris ISP-1 and Burkholderia rabicn ISOP5 improved yield and increased soil fertility and metabolic activity [134]. These authors conducted gene functional analysis with PICRUSt 1.1.4 and found that the abundances of the genes associated with inorganic P solubilization, organic P mineralization and $\mathrm{N}$ metabolism was remarkably increased. They noticed that the abundance of the phylum Verrucomicrobia 
was significantly increased in this treatment [134]. It has been deduced that the bacteria belonging to Verrucomicrobia are associated with soil fertility, which plays an important role in the degradation of organic matter $[134,135]$. Taken together, these results shown that inoculation with PNSB could improve soil fertility and enzymatic activities by altering the abundances of related bacteria and functional gene expression.

\subsection{PNSB as Biological Control Agents}

Biocontrol refers to the use of other organisms to control pests, like insects, mites, weeds and plant diseases [136]. Plant diseases cause damage to crop yield, reproduction, photosynthetic activity and growth [137]. In addition to using chemical pesticides, plant diseases can be controlled through biocontrol, which is regarded as an environmentally friendly alternative approach to suppress plant pathogens through the application of living organisms [138]. PGPR also play a major role in biocontrol by producing pathogen-antagonistic substances and/or by inducing systematic resistance in plants to pathogens [139]. PGPR-elicited ISR enhances the defensive capacity of host plants and reduces damage from pathogens [140]. Su and colleagues reported that inoculating R. palustris GJ-22 onto tobacco (Nicotiana benthamiana) leaves could induce ISR to TMV [73,74]. The abundance of TMV was reduced to a remarkable extent, the activities of defensive enzymes were enhanced and the transcripts of pathogenesis-related (PR) genes were upregulated $[73,74]$. Furthermore, such ISR has been demonstrated to be triggered by an exopolysaccharide, G-EPS, secreted by R. palustris GJ-22 [141].

\section{Developing Elite PNSB Inoculants for Sustainable Agriculture}

In general, several beneficial microbial traits (i.e., in vitro PGP traits), such as BNF, phosphate solubilization, 1-aminocyclopropane-1-carboxylic acid (ACC) deaminase activity and siderophore and phytohormone production, are assessed via laboratory screening assays to select elite PGPR for the development of microbial inoculants [142]. However, many reports have already indicated that the existence of these PGP microbial traits in vitro is not absolutely associated with plant growth promotion $[143,144]$. Taking PNSB as an example, PS3, YSC3 and BCRC16408 (ATCC $17001^{\mathrm{T}}$ ) are three closely related R. palustris strains [45]. These three strains were able to fix nitrogen under a free-living state and produce IAA in the presence of tryptophan; however, only PS3 was proven to be able to improve plant growth [45]. Furthermore, Lo and colleagues reported that the PS3 and YSC3 strains possessed very similar genome structures and genes associated with plant growth promotion; however, only PS3 showed beneficial effects on plant growth [89]. Accordingly, these findings all indicate that the in vitro presence of PGP traits or PGP-related genes does not necessarily indicate phenotypes associated with plant growth promotion.

The application of PGPR inoculants is an effective biological approach to increase crop yields. However, the effectiveness of a PGPR inoculant in the field depends on a various factors, such as environmental conditions, plant types, microbe-plant interactions and indigenous microbial communities [145]. Many studies have elucidated the mechanisms of PGPR inoculant with single strain and single host plants [146]. However, PGPR strains do not act individually in the rhizosphere but rather as part of a bacterial community [146]. PGPR populations may display antagonistic or synergistic effects, depending on their interaction with microbial communities [146]. Therefore, the complexity of interactions between PGPR and the resident microbiome needs to be considered when inoculants are applied to the field. A previous work showed that while inoculating PNSB on some plant species, Proteobacteria, Planctomycetes, Acidobacteria, Actinobacteria, Verrucomicrobia and Nitrospirae, increased in the rhizosphere $[47,48]$. Accordingly, they deduced that these nutrient cycle related phyla acted synergistically with the PNSB inoculant to improve plant biomass. However, there is no further physiological or molecular evidence to verify the roles of the microbial phyla in the rhizosphere. Recently, Santoyo and colleagues proposed expanding the use different microbial consortia to provide more consistent results and performance in the fields [147]. 
In general, the performances of PGPR inoculants under laboratory or greenhouse conditions are not easily transferred to those under field conditions, particularly when dealing with gram-negative, non-spore-forming bacteria [148]. These microbes do not form spores or go dormant and they are more susceptible than other bacteria to detrimental factors occurring during processing and field application $[149,150]$. Without appropriate formulations, microbial inoculants of non-spore-forming bacteria are easily damaged during processing, cannot be easily stored for long periods under harsh conditions (i.e., they have a short shelf life), or do not easily survive in the rhizosphere after application [151].

To enhance the survival rate and effectiveness of non-spore-forming bacteria in inoculants, it is necessary to develop suitable formulations [151]. PNSB are non-spore-forming bacteria and according to a previous study, most are applied to soil in liquid form. The advantages of liquid-based inoculants are their easy processing and the low costs of additive materials compared to those for solid-based formulations [152]. Common additive materials, such as coconut water, polyvinyl alcohol, xanthan gum, gelatin, mineral oil and rabic gum, can prolong cell survival during storage [153-158]. On the other hand, because liquid-based inoculants are packaged for long-term storage, they are subject to several abiotic stresses, such as nutrient depletion, extreme temperatures or hypoxia $[151,159,160]$. Proper formulation can mitigate those stresses during storage to a certain extent. In the case of $R$. palustris, Lee and colleagues found that horticultural oil was a safe and low-cost additive for formulations [155]. This oil can act as an additional nutrient source, allowing R. palustris to maintain growth during storage and after application [155]. There is also an increasingly popular formulation technique for liquid-based inoculants that involves biochar. Biochar is a charcoal-like substance that is made by burning organic material and can adsorb beneficial bacteria, as well as organic ingredients, due to its high internal porosity and large surface area [161-163]. It has been reported that encapsulating bacteria in or coating bacteria with biochar material could form a habitat and protect the bacteria from stressful conditions to prolong their survival [164-166]. Although biochar-based formulation is a potentially promising technique, in consideration of its cost as well as concern over its potential toxicity, further evaluation is needed [167].

\section{PNSB Inoculants Can Improve the Quality and Nutritional Value of Food Crops}

It has been well studied that PGPR application can also improve the quality and nutritional value of agricultural products [168]. For example, Sharma's research group reported that the inoculation with Pseudomonas putida, Pseudomonas fluorescens and Azospirillum lipoferum enhanced the grain iron content in rice [169]. Kondo and colleagues reported that application of $R$. sphaeroides increased the quality of tomato plants [55]. In addition, Yildirim and colleagues demonstrated that broccoli roots inoculated with PGPR (Bacillus cereus, Brevibacillus reuszeri and Rhizobium rubi) could increase dietary nutritional values, such as N, K, Ca, S, P, Mg, Fe, Mn, $\mathrm{Zn}$ and $\mathrm{Cu}$ [170].

Some leafy vegetables, such as spinach, parsley, fennel and rocket, tend to accumulate high levels of nitrates and excess $\mathrm{N}$ supply is considered to be the major cause of nitrate accumulation [107,171-173]. In consideration of the undesirable effects on human health, the EU has set the regulation for the levels of nitrates in leafy vegetables [174,175]. Nonheading Chinese cabbage ( $B$. rapa var. chinensis) is a popular Asian leafy vegetable with a relatively high nitrate concentration [176]. Hsu and colleagues found that while inoculating an elite PNSB strain R. palustris PS3 in the hydroponic nutrient solution during cultivation of non-heading Chinese cabbage, not only was the yield increased, but also the nitrate content was remarkably decreased by $88 \%$ [41]. Intriguingly, although the nitrate uptake was significantly elevated in the PS3-inoculated plants, the excess nitrate was not accumulated in the tissues [42]. This is because the plants showed high $\mathrm{N}$ use efficiency (NUE) in the presence of $R$. palustris PS3 [42].

PNSB has also shown the potential to enhance the contents of a variety of secondary metabolites in crops [53,79]. For example, R. palustris KL9 was reported to enhance the lycopene content in harvested tomato fruits. $R$. sphaeroides KE149 was reported to increase the 
production of flavonoids and phenolics in soybean under normal condition [79]. Both lycopene and flavonoids have been shown to have antioxidative activities, which can provide positive effects for the maintenance of health and the prevention of diseases, such as chronic diseases, including cancer, asthma, inflammation, cardiovascular disorders, etc [177,178]. $\mathrm{Wu}$ and colleagues reported that while treating Stevia rebaudiana with Rhodopseudomonas sp. ISP-1 resulted in a dramatic increase in the stevioside content in leaves. Stevioside is a steviol glycoside which are the secondary metabolites responsible for the sweetness of Stevia. This compound is used as a natural sweetener for type II diabetic patients and safe to consume in appropriate dosage $[179,180]$. These findings all indicate that PNSB can improve the quality as well as elevate the accumulation of secondary metabolites of agri-food products effectively. Taken together, we believe the application of PNSB in medicinal plants and health is worthy of further exploration.

\section{Our Research and Development Journey to PSB as Elite PGPR Inoculants}

As described in the previous sections, PNSB have many traits that confer benefits to plant growth, such as increased crop yield and harvest quality, or tolerance to stressful environments. Since PNSB possess versatile functions, they have the potential to become elite microbial inoculants, such as biofertilizers or biostimulants. Hereinafter, we share our experiences researching and developing an R. palustris inoculant. The experimental strategy to develop the inoculant based on R. palustris PS3 is shown in Figure 2.
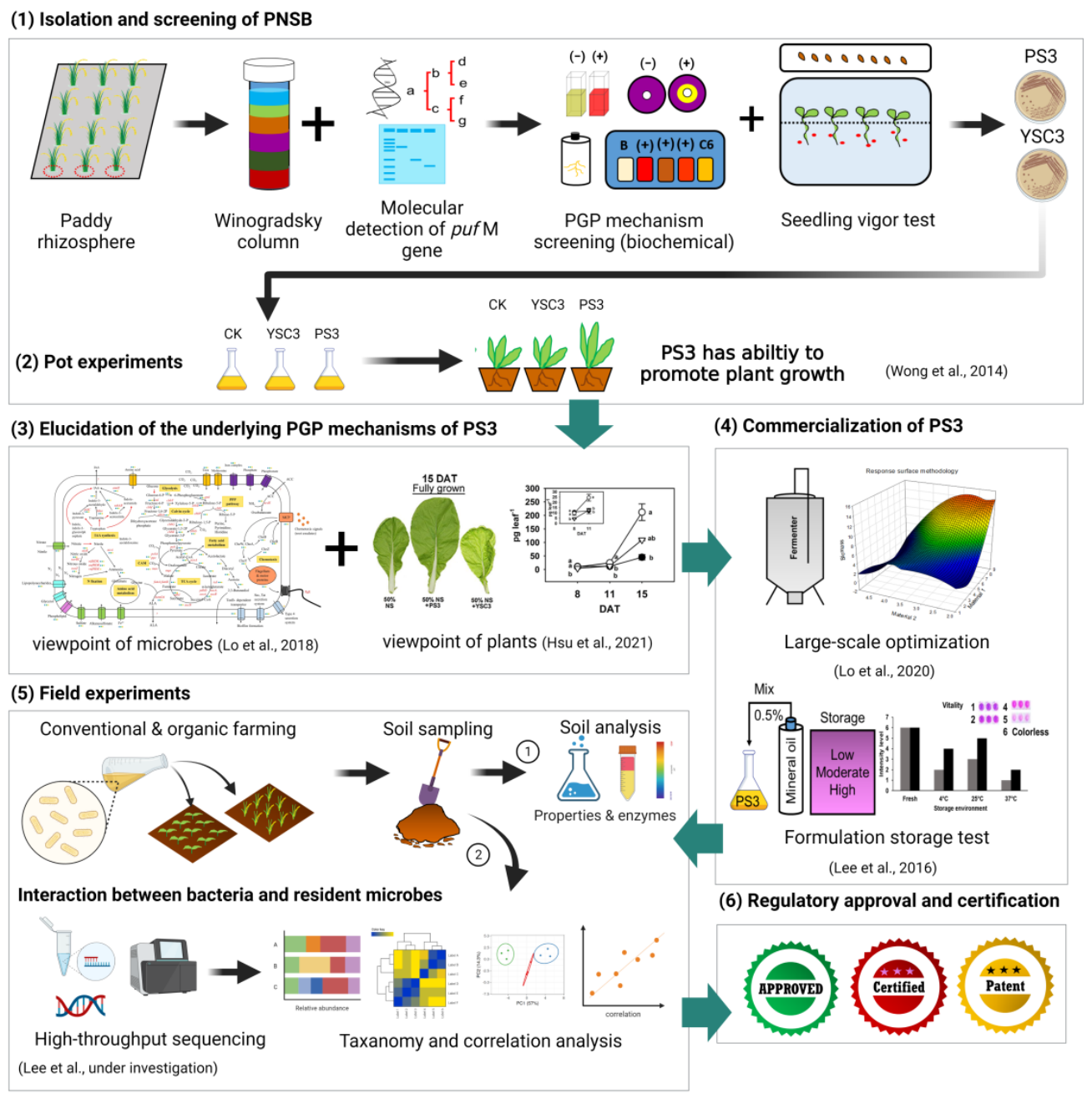

Figure 2. Diagram of the research and development processes of the R. palustris PS3 inoculant: (1) Isolate and screen of PNSB; (2) perform pot experiments to verify the PGP efficiency of isolates; (3) elucidate the 
underlying PGP mechanisms of PS3 from the viewpoint of microbes and plants; (4) develop optimal fermentation and formulation processes for commercialization; (5) perform field experiments to verify the efficacy and performance of the PS3 inoculant under conventional and organic farming conditions; (6) obtain regulatory approval and certification of the PS3 inoculant as a biofertilizer or plant biostimulant. This illustration was created at BioRender.com (accessed on 20 November 2021).

\subsection{Isolation and Screening of PNSB}

PNSB are widely found in nature, especially in submerged environments, such as paddy fields and sediments [181]. To efficiently isolate PNSB, we combined the conventional Winogradsky soil column and molecular marker ( $p u f M$ gene) detection methods to enrich and isolate microbes from rice paddy fields located all around Taiwan [45]. We initially conducted in vitro screening for PGP traits to select potential isolates. However, we noticed that many isolates that exhibited relative high potency in vitro PGP traits were not necessarily able to promote plant growth (data not shown). We alternatively conducted a seedling vigor test, through which we pre-evaluate the compatibility and incompatibility of the isolates and host plants [45]. We selected several strains from the PNSB isolates and PS3 showed the highest seedling vigor index among the selected strains [45].

\subsection{Pot Experiments}

In consideration of the adverse environmental impacts of agrochemicals and to support sustainable agricultural development, many countries have set goals for reducing the application of these chemicals in agriculture [182]. In Taiwan, it has been proposed that agrochemical use should be reduced by $30-50 \%$ in the long term. Accordingly, we set a criterion to select promising PNSB inoculants that can sustain proper crop yield even under half of the conventional fertilizer dosage. We inoculated the potential PNSB isolates into soil ( $10^{6} \mathrm{CFU} / \mathrm{g}$ soil) cultivated with Chinese cabbage (Brassica rapa L. ssp. chinensis var. Maruha) with half the typical rate of chemical fertilizer ( $50 \% \mathrm{CF})$. We then evaluated the agronomic characteristics of 30-day-old Chinese cabbage plants [45]. The growth of plants in the treatment with $50 \%$ CF only was markedly less than that in the treatment with the full amount of chemical fertilizer $(100 \%$ CF). However, when the PS3 inoculant was added to the treatment with $50 \% \mathrm{CF}$, the plant biomass (fresh and dry weights of the shoots) was significantly greater than that in the treatment with $50 \% \mathrm{CF}$ alone and statistically comparable to that in the treatment with $100 \% \mathrm{CF}$. On the other hand, when $50 \%$ fertilizer was combined with the other PNSB isolates, lower growth or inconsistent growth was observed compared with that in the treatment with 100\% CF [45]. Many rounds of trials were conducted to confirm the growth-promoting traits of PS3 and we determined that PS3 has the potential to promote plant growth even with less fertilizer input than is typically applied. According to the results of molecular phylogenetic analysis and biochemical characterization, strain PS3 was identified as R. palustris, which is a facultatively phototrophic/chemotrophic PNSB [45].

\subsection{Elucidation of the Underlying PGP Mechanisms of PS3 \\ 6.3.1. From the Viewpoint of Microbes}

Soil microorganisms play essential roles in plant growth and plant exudates by altering the internal physiological status of plants to different extents [92,183]. Root exudates may act as signaling messengers that stimulate biological and physical interactions between plant roots and soil organisms and affect the structures of microbial communities [184]. To elucidate the underlying mechanisms of the beneficial effects exerted by PS3, we explored the modes of action from the microbial and plant viewpoints. For comparative analyses, YSC3, a PGP-ineffective R. palustris strain, was introduced. According to a phylogenetic tree, the genetic relationship between YSC3 and PS3 was very close [45]. We conducted whole-genome sequencing analysis and found that the genomic structures of PS3 and YSC3 were very similar [89] (Supplementary Figure S1). Furthermore, both strains possessed genes associated with plant growth promotion, such as those related to nitrogen fixation, 
IAA synthesis and ACC deamination [89]. However, we found that when treating Chinese cabbage roots with exudate solutions containing each strain, the growth rate, amount of biofilm formation and relative expression levels of several chemotaxis-associated genes were significantly higher for the plants in the PS3 treatment than for those in the YSC3 treatment [89] (summarized in Figure 3). These results indicate that PS3 responds more sensitively than YSC3 to the presence of plant hosts, which may contribute to the successful interactions of PS3 with plant hosts. In addition, we demonstrated that the existence of gene clusters associated with PGP is required for a bacterium to exhibit phenotypes associated with beneficial effects; however, the presence of these genes does not necessarily indicate their expression [89]. Therefore, the effectiveness of PGPR is not necessarily coupled with their genetic background or in vitro characteristics.

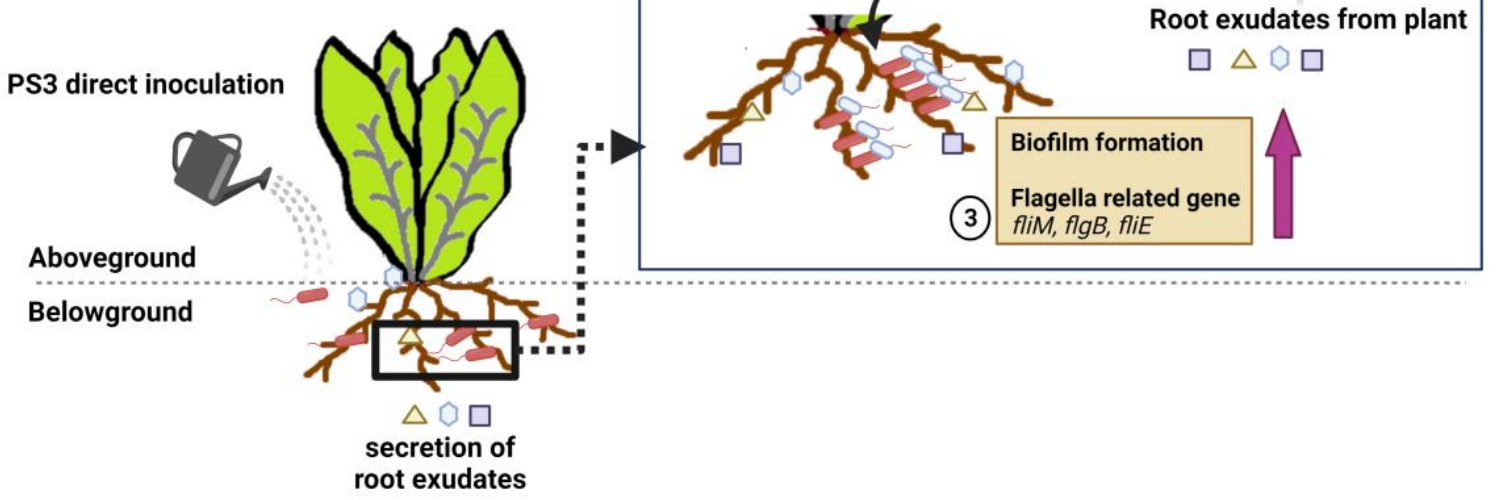

Figure 3. A deduced plant-growth promoting mechanism based on the viewpoint of microbes (refer to Lo et al., 2018) [89]. (1) R. palustris PS3 cells are attracted by the root exudate of the host plant (i.e., chemotactic response); (2) Cell growth of PS3 is induced in the presence of root exudates; and (3) PS3 cells move close to roots and colonize the surface of roots by forming biofilms. This illustration was created at BioRender.com (accessed on 20 November 2021).

\subsubsection{From the Viewpoint of Plants}

The shoot biomass of PS3-inoculated Chinese cabbage was significantly higher than that of YSC3-inoculated Chinese cabbage [45], which was mainly due to the enlargement of the leaf area of young expanding leaves [42]. Since there were no significant differences in leaf number among the treatment groups, we deduced that the beneficial effect in shoot biomass was due to leaf area expansion rather than elevation in the number of leaf blades. Auxins are responsible for many aspects of plant growth and we found that the endogenous IAA level in the leaves of the PS3-inoculated plants was significantly higher than that in the YSC3-inoculated plants. Some literature has indicated that there is a positive correlation between endogenous auxin levels in host plants and exogenous auxin production by beneficial microbes $[185,186]$. However, exogenous auxin production by PS3 was not higher than that by YSC3 and auxin production by these strains was equal in the presence of tryptophan [45]. We further verified the bacterial expression of IAA synthesis-related genes during root colonization and found the same expression level between strains [42]. Accordingly, we deduced that auxin accumulation in the shoots of 
the PS3-inoculated plants was systemically induced by the root-colonizing bacterium, not due to the direct transport of bacterial auxin from roots.

In addition to biomass, we found that the N content and the NUE of PS3-inoculated Chinese cabbage were dramatically higher than those of YSC3-inoculated plants [42]. As mentioned, NUE is associated with both NUpE and N assimilation efficiency (NUtE). In the PS3-inoculated plants, the former was significantly increased; however, the latter was almost the same as in the YSC3-inoculated plants. We analyzed the transcripts of some nitrate transporter-related genes in roots and found that the expression rate of the gene encoding a low affinity nitrate transporter (NRT 1.1) was significantly higher in PS3-inoculated plants than in YSC3-inoculated plants during the expanded leaf development stage [42].

Taken together, these results show that inoculation with PS3 could promote plant growth by enhancing nitrate uptake and stimulating the accumulation of endogenous auxin in young expanding leaves to increase the proliferation of leaf cells during leaf development [42] (summarized in Figure 4). We concluded that all the differences between the PS3- and YSC3-inoculated plants were due to the differences in responses elicited by compatible and incompatible bacterium-plant interactions.

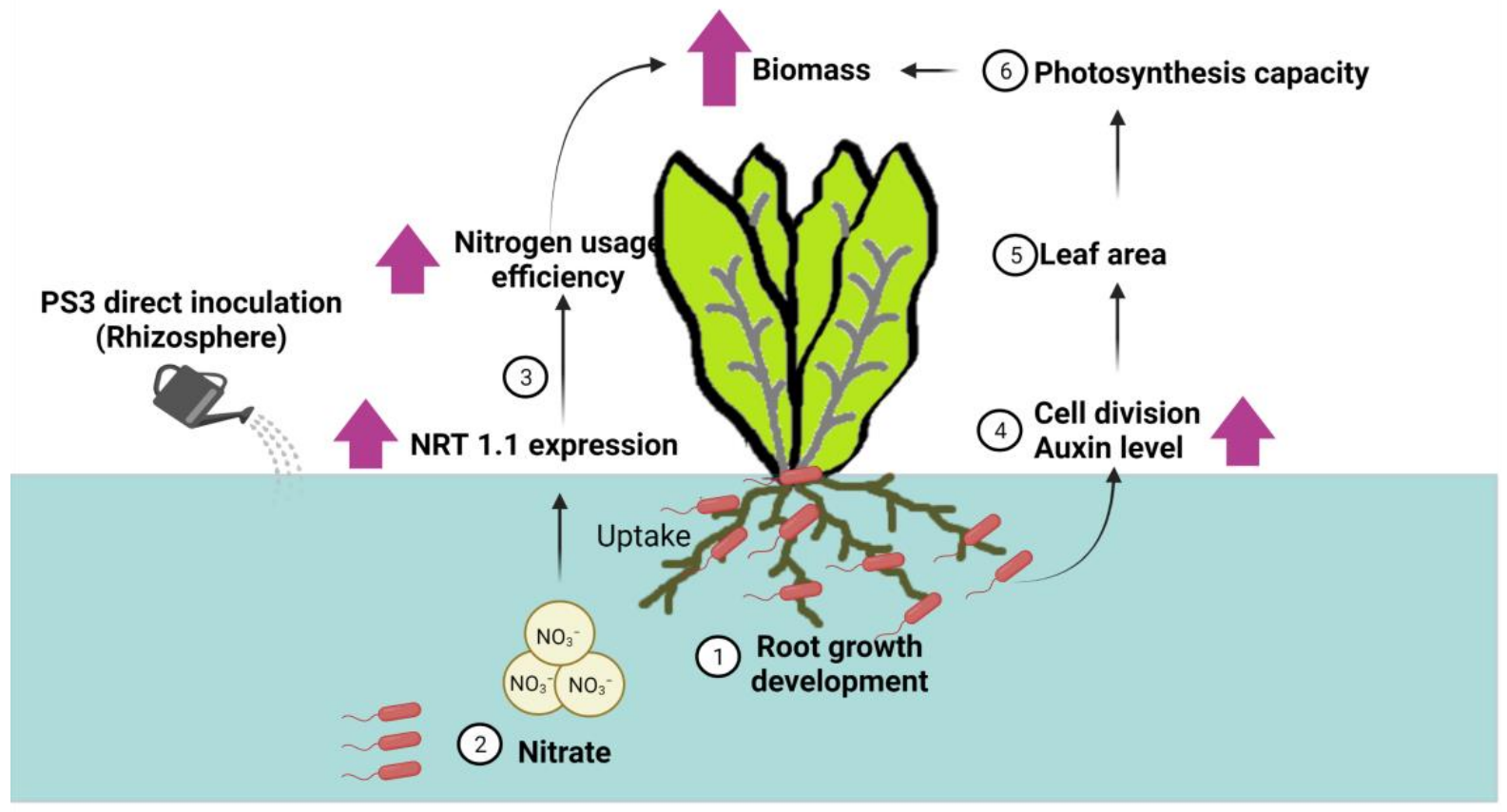

Figure 4. A deduced plant-growth promoting mechanism based on the viewpoint of plants (refer to Hsu et al., 2021) [42]. Here, we show the interaction between R. palustris PS3 and Chinese cabbage cultivated in a hydroponic system. (1) PS3 cells stimulate root growth and development; (2) nitrate uptake of Chinese cabbage is increased by PS3 inoculation (i.e., NRT1.1 transcript increased); (3) nitrogen use efficiency (NUE) of Chinese cabbage is remarkably enhanced; (4) endogenous IAA concentration as well as cell division rate are significantly increased in the young expanding leaves; (5) leaf size is remarkably enlarged; and (6) photosynthetic capacity of plant is notably increased. (Patent: method of reducing nitrite content in a plant, US10,015,935,B2). This illustration was created at BioRender.com (accessed on 20 November 2021).

\subsection{Optimal Fermentation and Formulation}

There are a number of factors, such as the large-scale of commercial manufacturing, the suitability of formulations and the methods of application, that influence the quality and efficacy of microbial inoculants during production and processing and after inoculation into soil. For large-scale commercial manufacturing, optimizing the fermentation process is an essential step. To develop an optimal fermentation protocol for R. palustris PS3, we evaluated the use of low-cost materials as culture media and optimized the culture conditions via the response surface methodology [187]. We developed a novel medium for R. palustris fermentation with agro-industrial byproducts, i.e., corn steep liquor (CSL) and 
molasses, as nitrogen and carbon sources [187]. In addition, we applied response surface methodology to determine the optimum fermentation process and the effectiveness of the new fermentation broth was verified by pot experiments [187]. Our newly developed medium and process for large-scale industrial production provide a prospective strategy with the benefits of cost and time effectiveness, as well as environmental sustainability.

The inconsistent efficacy of PGPR inoculants in field conditions, which usually do not perform as well as those in greenhouse or laboratory experiments, has been widely discussed [188,189]. In most cases, this gap in performance is due to inadequate formulation and poor inoculant quality [190-192]. As mentioned, R. palustris are nonspore-forming bacteria that are difficult to formulate into solid-based inoculants. To develop a PS3 inoculant for practical use, we evaluated several oil- and polymer-based additives for PS3 formulation development. We analyzed the survival of PS3 in various formulations and at different storage temperatures for a set period of time and assessed the beneficial effects of these inoculants on plants grown in pots. We ultimately chose horticultural oil $(0.5 \%)$ as a potential additive because it maintained a relatively large population of bacteria and conferred greater microbial vitality than other additives under various storage conditions [155]. Better plant growth-promoting effects were observed in the treatment with the formulated PS3 inoculant than in the treatment without the inoculant [155] (summarize in Figure 5). Intriguingly, we noticed that although the survival and root colonization were almost identical in the formulated and unformulated treatments, higher recovery activities during storage and greater plant growth promotion were observed in the formulated treatment than in the unformulated treatment [155]. Accordingly, to address the gaps between the expected and actual performances of PGPR inoculants, we suggest that not only the viability (i.e., cultivability) but also the vitality (i.e., metabolic activity) of bacteria should be considered indices of quality control.

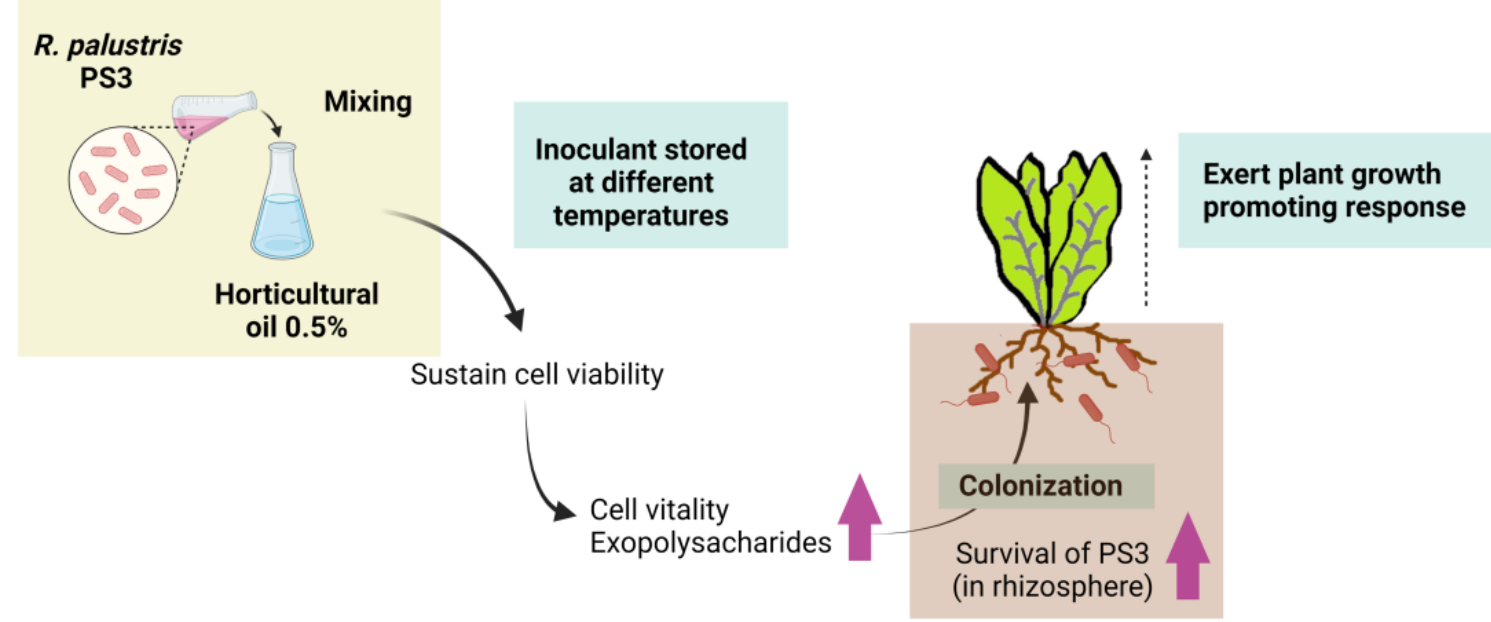

Figure 5. Beneficial effects of horticultural oil as a potential additive for liquid-based formulation of R. palustris PS3 inoculant (refer to Lee et al., 2016) [155]. After supplementing $0.5 \%$ horticultural oil in the bacterial broth, both the viability (i.e., culturability) and vitality (i.e., metabolic activity) of PS3 cells were remarkably improved even after storage at relatively high temperatures. The exopolysaccharide (EPS) content in the formulated inoculants was significantly increased and was favorable for colonization on the surface of roots. When inoculated with plants, the formulated PS3 inoculants showed a greater ability to survive in soil and exert plant growth-promoting traits than the unformulated inoculants. This illustration was created at BioRender.com (accessed on 20 November 2021).

\subsection{Field Experiments}

It has been reported that the efficacy and performance of PGPR inoculants under field conditions are affected by plant species and varieties, geographical and climatic conditions, soil physicochemical environments and the application of chemical fertilizers or pesticides [193-195]. The effectiveness of PS3 for plant growth promotion was verified in 
various farming systems (Supplementary Table S2). For conventional farming systems, the yield of heading Chinese cabbage inoculated with PS3 and given half the normal amount of chemical fertilizer was $\sim 39 \%$ and $\sim 23 \%$ higher than those that were not inoculated and given half and full amounts of chemical fertilizer, respectively. PS3 inoculation also benefited the yield of Chinese flowering cabbage (Choi Sum) and pepper leaves when these plants were cultivated under conventional farming systems with organic amendment. For organic farming systems, the performance of PS3 was determined in both cruciferous vegetables and plants belonging to Asteraceae, such as Chinese cabbage, lettuce and sesame leaves. Consumable yields of these crops significantly increased by $25-43 \%$ compared with that of the control (without inoculation). Notably, PS3 inoculation also had beneficial effects on tomato fruit growth, taste and harvesting quality in organic farming systems (Lee et al., unpublished data). The long-term changes in plant growth, the physicochemical properties of soil, soil enzymatic activities and rhizosphere microbial community dynamics caused by the application of PS3 are under investigation. We expect this study to enhance our mechanistic understanding of the interactions between plants and microbes and how these processes can be optimized to drive plant nutrition with organic fertilizers.

\section{Conclusions and Perspective}

PNSB are versatile microorganisms that are able to exert plant growth-promoting effects on crops and are discussed in this review (Section 2). In this review, we summarize examples of PNSB through biofertilization, biostimulation and biocontrol mechanisms to promote plant growth. They can improve plant growth by fixing nitrogen, facilitating nutrient acquisition and producing phytohormones. Furthermore, they are able to synthesize 5-ALA to confer abiotic stress tolerance to host plants (Section 3). Under biotic stress, they may trigger ISR and enhance bacterial colonization by beneficial bacteria to protect plants from pathogen attack (Section 3). In addition, PNSB can regulate microbial communities to enhance soil fertility elements, which consequently have beneficial effects on the nutrient use efficiency and quality of plants (Section 3). Since PNSB are nonspore-forming bacteria, their performance in the field is easily affected by environmental conditions. To enhance their survival rate and effectiveness, a suitable formulation is needed for the commercialization of these inoculants (Section 4). In addition, PNSB are found to improve the quality and trigger the accumulation of secondary metabolites of food crops (Section 5). Accordingly, it is worth further exploring the application of PNSB in medicinal plants and human health. We also share our experiences researching and developing the elite R. palustris PS3 inoculant (Section 6). Based on the experimental results, we suggest that not only the viability (i.e., cultivability) but also the vitality (i.e., metabolic activity) of PGPR should be considered indices of quality control for microbial inoculants. Given their beneficial effects and wide applicability to crops, PNSB are promising inoculants in sustainable agriculture and provide a solution to crop production under climate change.

Supplementary Materials: The following are available online at https:/ /www.mdpi.com/article/10 .3390 / microorganisms 9122453 /s1, Figure S1: Genes potentially related to plant growth promotion and biofilm formation in different strains of PS3, YSC3, and CGA009, Table S1: Beneficial effects of PNSB on different crops and Table S2: Plant growth responses to PS3 inoculation under different experimental conditions and farming systems.

Author Contributions: Conceptualization, S.-K.L., H.-S.L., C.-T.L.; writing-original draft preparation, S.-K.L., C.-T.L.; review and editing, AJE English editing service; supervision, H.-S.L., C.-T.L.; funding acquisition, C.-T.L. All authors have read and agreed to the published version of the manuscript.

Funding: This study was supported by grants from the Ministry of Science and Technology (1082313-B-002-058-MY3, MOST 109-2321-B-005-027).

Institutional Review Board Statement: Not applicable.

Informed Consent Statement: Not applicable. 


\section{Data Availability Statement: Not applicable.}

Conflicts of Interest: The authors declare no conflict of interest.

\section{References}

1. Backer, R.; Rokem, J.S.; Ilangumaran, G.; Lamont, J.; Praslickova, D.; Ricci, E.; Subramanian, S.; Smith, D.L. Plant growthpromoting rhizobacteria: Context, mechanisms of action, and roadmap to commercialization of biostimulants for sustainable agriculture. Front. Plant Sci. 2018, 9, 1473. [CrossRef] [PubMed]

2. Basu, A.; Prasad, P.; Das, S.N.; Kalam, S.; Sayyed, R.Z.; Reddy, M.S.; El Enshasy, H. Plant growth promoting rhizobacteria (pgpr) as green bioinoculants: Recent developments, constraints, and prospects. Sustainability 2021, 13, 1140. [CrossRef]

3. Habib, S.H.; Kausar, H.; Saud, H.M. Plant growth-promoting rhizobacteria enhance salinity stress tolerance in okra through ROS-scavenging enzymes. BioMed Res. Int. 2016, 2016, 6284547. [CrossRef]

4. Chandini, R.K.; Kumar, R.; Om, P. The Impact of Chemical Fertilizers on our Environment and Ecosystem. Research Trends in Environmental Sciences, 2nd ed.; AkiNik Publications: Delhi, India, 2019; pp. 71-86.

5. Farhadinejad, T.; Khakzad, A.; Jafari, M.; Shoaee, Z.; Khosrotehrani, K.; Nobari, R.; Shahrokhi, V. The study of environmental effects of chemical fertilizers and domestic sewage on water quality of Taft region, Central Iran. Arab. J. Geosci. 2014, 7, 221-229. [CrossRef]

6. Hartmann, M.; Frey, B.; Mayer, J.; Mäder, P.; Widmer, F. Distinct soil microbial diversity under long-term organic and conventional farming. ISME J. 2015, 9, 1177-1194. [CrossRef] [PubMed]

7. Wang, B.; Shugart, H.H.; Lerdau, M.T. Sensitivity of global greenhouse gas budgets to tropospheric ozone pollution mediated by the biosphere. Environ. Res. Lett. 2017, 12, 084001. [CrossRef]

8. Westarp, S.V.; Sandra Brown, H.S.; Shah, P. Agricultural intensification and the impacts on soil fertility in the middle mountains of Nepal. Can. J. Soil Sci. 2004, 84, 323-332. [CrossRef]

9. Pimentel, D.; Wilson, A. World population, agriculture and malnutrition. World Watch 2004, 17, $22-25$.

10. Fróna, D.; Szenderák, J.; Harangi-Rakos, M. The challenge of feeding the world. Sustainability 2019, 11, 5816. [CrossRef]

11. Riaz, U.; Mehdi, S.M.; Iqbal, S.; Khalid, H.I.; Qadir, A.A.; Anum, W.; Ahmad, M.; Murtaza, G. Bio-fertilizers: Eco-Friendly approach for plant and soil environment. In Bioremediation and Biotechnology; Springer: Berlin/Heidelberg, Germany, 2020; pp. 189-213.

12. Castiglione, A.M.; Mannino, G.; Contartese, V.; Bertea, C.M.; Ertani, A. Microbial biostimulants as response to modern agriculture needs: Composition, role and application of these innovative products. Plants 2021, 10, 1533. [CrossRef] [PubMed]

13. Kloepper, J.W.; Leong, J.; Teintze, M.; Schroth, M.N. Enhanced plant growth by siderophores produced by plant growth-promoting rhizobacteria. Nature 1980, 286, 885-886. [CrossRef]

14. Martínez-Viveros, O.; Jorquera, M.; Crowley, D.; Gajardo, G.; Mora, M. Mechanisms and practical considerations involved in plant growth promotion by rhizobacteria. J. Soil Sci. Plant Nutr. 2010, 10, 293-319. [CrossRef]

15. Adesemoye, A.O.; Yuen, G.; Watts, D.B. Microbial inoculants for optimized plant nutrient use in integrated pest and input management systems. In Probiotics and Plant Health; Kumar, V., Kumar, M., Sharma, S., Prasad, R., Eds.; Springer: Singapore, 2017; pp. 21-40.

16. Bhattacharyya, P.N.; Jha, D.K. Plant growth-promoting rhizobacteria (PGPR): Emergence in agriculture. World J. Microbiol. Biotechnol. 2012, 28, 1327-1350. [CrossRef]

17. Govindasamy, V.; Senthilkumar, M.; Annapurna, K. Effect of mustard rhizobacteria on wheat growth promotion under cadmium stress: Characterization of acdS gene coding ACC deaminase. Ann. Microbiol. 2015, 65, 1679-1687. [CrossRef]

18. Cordero, I.; Balaguer, L.; Rincón, A.; Pueyo, J.J. Inoculation of tomato plants with selected PGPR represents a feasible alternative to chemical fertilization under salt stress. J. Plant Nutr. Soil Sci. 2018, 181, 694-703. [CrossRef]

19. Islam, S.; Akanda, A.M.; Prova, A.; Islam, M.T.; Hossain, M.M. Isolation and identification of plant growth promoting rhizobacteria from cucumber rhizosphere and their effect on plant growth promotion and disease suppression. Front. Microbiol. 2016, 6, 1360. [CrossRef]

20. Krey, T.; Vassilev, N.; Baum, C.; Eichler-Löbermann, B. Effects of long-term phosphorus application and plant-growth promoting rhizobacteria on maize phosphorus nutrition under field conditions. Eur. J. Soil Biol. 2013, 55, 124-130. [CrossRef]

21. Kurokura, T.; Hiraide, S.; Shimamura, Y.; Yamane, K. PGPR improves yield of strawberry species under less-fertilized conditions. Environ. Control Biol. 2017, 55, 121-128. [CrossRef]

22. Stefan, M.; Munteanu, N.; Stoleru, V.; Marius, M. Effects of inoculation with plant growth promoting rhizobacteria on photosynthesis, antioxidant status and yield of runner bean. Rom. Biotechnol. Lett. 2013, 18, 12.

23. Baber, M.; Fatima, M.; Mansoor, M.; Naz, S.; Hanif, M.; Naqqash, T. Weed rhizosphere: A source of novel plant growth promoting rhizobacteria (PGPR). Int. J. Biosci. (IJB) 2018, 13, 224-234.

24. Beneduzi, A.; Ambrosini, A.; Passaglia, L.M.P. Plant growth-promoting rhizobacteria (PGPR): Their potential as antagonists and biocontrol agents. Genet. Mol. Biol. 2012, 35, 1044-1051. [CrossRef]

25. Maheshwari, D.K.; Dheeman, S.; Agarwal, M. Phytohormone-producing PGPR for sustainable agriculture. In Bacterial Metabolites in Sustainable Agroecosystem; Maheshwari, D.K., Ed.; Springer International Publishing: Cham, Switzerland, 2015 ; pp. 159-182. 
26. Santoro, M.; Cappellari, L.; Giordano, W.; Banchio, E. Production of volatile organic compounds in PGPR. In Handbook for Azospirillum: Technical Issues and Protocols; Cassán, F.D., Okon, Y., Creus, C.M., Eds.; Springer International Publishing: Cham, Switzerland, 2015; pp. 307-317.

27. Idi, A.; Md Nor, M.H.; Abdul Wahab, M.F.; Ibrahim, Z. Photosynthetic bacteria: An eco-friendly and cheap tool for bioremediation. Rev. Environ. Sci. Bio/Technol. 2015, 14, 271-285. [CrossRef]

28. Imhoff, J.F. The Phototrophic Alpha-Proteobacteria. In The Prokaryotes: Volume 5: Proteobacteria: Alpha and Beta Subclasses; Dworkin, M., Falkow, S., Rosenberg, E., Schleifer, K.-H., Stackebrandt, E., Eds.; Springer: New York, NY, USA, 2006 ; pp. 41-64.

29. Larimer, F.W.; Chain, P.; Hauser, L.; Lamerdin, J.; Malfatti, S.; Do, L.; Land, M.L.; Pelletier, D.A.; Beatty, J.T.; Lang, A.S. Complete genome sequence of the metabolically versatile photosynthetic bacterium Rhodopseudomonas palustris. Nat. Biotechnol. 2004, 22, 55-61. [CrossRef]

30. Pechter, K.B.; Gallagher, L.; Pyles, H.; Manoil, C.S.; Harwood, C.S. Essential genome of the metabolically versatile alphaproteobacterium Rhodopseudomonas palustris. J. Bacteriol. 2016, 198, 867-876. [CrossRef] [PubMed]

31. Holguin, G.; Vazquez, P.; Bashan, Y. The role of sediment microorganisms in the productivity, conservation, and rehabilitation of mangrove ecosystems: An overview. Biol. Fertil. Soils 2001, 33, 265-278. [CrossRef]

32. Crovadore, J.; Xu, S.; Chablais, R.; Cochard, B.; Lukito, D.; Calmin, G.; Lefort, F. Metagenome-assembled genome sequence of Rhodopseudomonas palustris strain eli 1980, commercialized as a biostimulant. Genome Announc. 2017, 5, e00221-17. [CrossRef] [PubMed]

33. Hiraishi, A.; Kitamura, H. Distribution of phototrophic purple nonsulfur bacteria in activated sludge systems and other aquatic environments. Nippon. Suisan Gakkaishi 1984, 50, 1929-1937. [CrossRef]

34. Oda, Y.; Wanders, W.; Huisman, L.A.; Meijer, W.G.; Gottschal, J.C.; Forney, L.J. Genotypic and phenotypic diversity within species of purple nonsulfur bacteria isolated from aquatic sediments. Appl. Environ. Microbiol. 2002, 68, 3467-3477. [CrossRef] [PubMed]

35. Alloul, A.; Wille, M.; Lucenti, P.; Bossier, P.; Van Stappen, G.; Vlaeminck, S.E. Purple bacteria as added-value protein ingredient in shrimp feed: Penaeus vannamei growth performance, and tolerance against Vibrio and ammonia stress. Aquaculture 2021, 530, 735788. [CrossRef]

36. Bunraksa, T.; Kantachote, D.; Chaiprapat, S. The potential use of purple nonsulfur bacteria to simultaneously treat chicken slaughterhouse wastewater and obtain valuable plant growth promoting effluent and their biomass for agricultural application. Biocatal. Agric. Biotechnol. 2020, 28, 101721. [CrossRef]

37. Gao, R.; Wang, Y.; Zhang, Y.; Tong, J.; Dai, W. Cobalt (II) bioaccumulation and distribution in Rhodopseudomonas palustris. Biotechnol. Biotechnol. Equip. 2017, 31, 527-534. [CrossRef]

38. Bai, W.; Ranaivoarisoa, T.O.; Singh, R.; Rengasamy, K.; Bose, A. Sustainable production of the biofuel n-Butanol by Rhodopseudomonas palustris TIE-1. bioRxiv 2020. [CrossRef]

39. Liu, C.-H.; Lee, S.-K.; Ou, I.-C.; Tsai, K.-J.; Lee, Y.; Chu, Y.-H.; Liao, Y.-T.; Liu, C.-T. Essential factors that affect bioelectricity generation by Rhodopseudomonas palustris strain PS3 in paddy soil microbial fuel cells. Int. J. Energy Res. 2021, 45, 2231-2244. [CrossRef]

40. Sakarika, M.; Spanoghe, J.; Sui, Y.; Wambacq, E.; Grunert, O.; Haesaert, G.; Spiller, M.; Vlaeminck, S.E. Purple non-sulphur bacteria and plant production: Benefits for fertilization, stress resistance and the environment. Microb. Biotechnol. 2020, 13, 1336-1365. [CrossRef] [PubMed]

41. Hsu, S.; Lo, K.; Fang, W.; Lur, H.; Liu, C. Application of phototrophic bacterial inoculant to reduce nitrate content in hydroponic leafy vegetables. Crop. Environ. Bioinform. 2015, 12, 30-41.

42. Hsu, S.H.; Shen, M.W.; Chen, J.C.; Lur, H.S.; Liu, C.T. The Photosynthetic bacterium Rhodopseudomonas palustris strain PS3 exerts plant growth-promoting effects by stimulating nitrogen uptake and elevating auxin levels in expanding leaves. Front. Plant Sci. 2021, 12, 573634. [CrossRef]

43. Kondo, K.; Nakata, N.; Nishihara, E. Effect of purple nonsulfur bacteria (Rhodobacter sphaeroides) on the growth and quality of komatsuna under different light qualities. Environ. Control. Biol. 2004, 42, 247-253. [CrossRef]

44. Kondo, K.; Nakata, N.; Nishihara, E. Effect of purple non-sulfur bacterium (Rhodobacter sphaeroides) application on the growth and quality of spinach and komatsuna. J. Jpn. Soc. Agric. Technol. Manag. 2008, 14, 198-203. [CrossRef]

45. Wong, W.-T.; Tseng, C.-H.; Hsu, S.-H.; Lur, H.-S.; Mo, C.-W.; Huang, C.-N.; Hsu, S.-C.; Lee, K.-T.; Liu, C.-T. Promoting effects of a single Rhodopseudomonas palustris inoculant on plant growth by Brassica rapa chinensis under low fertilizer input. Microbes Env. 2014, 29, 303-313. [CrossRef]

46. Wu, Y.; Jin, X.; Liao, W.; Hu, L.; Dawuda, M.M.; Zhao, X.; Tang, Z.; Gong, T.; Yu, J. 5-Aminolevulinic Acid (ALA) alleviated salinity stress in cucumber seedlings by enhancing chlorophyll synthesis pathway. Front. Plant Sci. 2018, 9, 635. [CrossRef] [PubMed]

47. Xu, J.; Feng, Y.; Wang, Y.; Lin, X. Effect of Rhizobacterium Rhodopseudomonas palustris Inoculation on Stevia rebaudiana plant growth and soil microbial community. Pedosphere 2018, 28, 793-803. [CrossRef]

48. Xu, J.; Feng, Y.; Wang, Y.; Luo, X.; Tang, J.; Lin, X. The foliar spray of Rhodopseudomonas palustris grown under Stevia residue extract promotes plant growth via changing soil microbial community. J. Soils Sediments 2016, 16, 916-923. [CrossRef]

49. Elbadry, M.; El-Bassel, A.; Elbanna, K. Occurrence and dynamics of phototrophic purple nonsulphur bacteria compared with other asymbiotic nitrogen fixers in ricefields of Egypt. World J. Microbiol. Biotechnol. 1999, 15, 359-362. [CrossRef] 
50. Elbadry, M.; Gamal-Eldin, H.; Elbanna, K. Effects of Rhodobacter capsulatus inoculation in combination with graded levels of nitrogen fertilizer on growth and yield of rice in pots and lysimeter experiments. World J. Microbiol. Biotechnol. 1999, 15, 393-395. [CrossRef]

51. Kang, S.-M.; Radhakrishnan, R.; You, Y.-H.; Khan, A.L.; Park, J.-M.; Lee, S.-M.; Lee, I.-J. Cucumber performance is improved by inoculation with plant growth-promoting microorganisms. Acta Agric. Scand. Sect. B-Soil Plant Sci. 2015, 65, 36-44. [CrossRef]

52. Lidder, S.; Webb, A.J. Vascular effects of dietary nitrate (as found in green leafy vegetables and beetroot) via the nitrate-nitrite-nitric oxide pathway. Br. J. Clin. Pharmacol. 2013, 75, 677-696. [CrossRef]

53. Lee, K.-H.; Koh, R.-H.; Song, H.-G. Enhancement of growth and yield of tomato by Rhodopseudomonas sp. under greenhouse conditions. J. Microbiol. 2009, 46, 641-646. [CrossRef]

54. Mujahid, M.; Sasikala, C.; Ramana, C.V. Production of indole-3-acetic acid and related indole derivatives from L-tryptophan by Rubrivivax benzoatilyticus JA2. Appl. Microbiol. Biotechnol. 2011, 89, 1001-1008. [CrossRef] [PubMed]

55. Kondo, K.; Nakata, N.; Nishihara, E. Effect of the purple non-sulfur bacterium (Rhodobacter sphaeroides) on the Brix, titratable acidity, ascorbic acid, organic acid, lycopene and beta-carotene in tomato fruit. J. Food Agric. Environ. 2010, 8, 743-746.

56. Kobayashi, M.; Tchan, Y.T. Treatment of industrial waste solutions and production of useful by-products using a photosynthetic bacterial method. Water Res. 1973, 7, 1219-1224. [CrossRef]

57. Li, Y.-L. Effect of photosynthetic bacterial on growth melon seedlings in early spring. N. Hortic. 2017, $22,76-79$.

58. Miao, J.-S.; Liu, J.; Liu, Y.-L.; Wu, J.-F. Effect of Photosynthetic bacterial on photosynthesis and antioxidant enzyme system of watermelon seedlings in early spring. North. Hortic. 2014, 21, 42-44.

59. Nayar, N. Origins and phylogeny of Rices; Elsevier: Amsterdam, The Netherlands, 2014.

60. Kobayashi, M.; Haque, M.Z. Contribution to nitrogen fixation and soil fertility by photosynthetic bacteria. Plant Soil 1971, 35, 443-456. [CrossRef]

61. Elbadry, M.; Elbanna, K. Response of four rice varieties to Rhodobacter capsulatus at seedling stage. World J. Microbiol. Biotechnol. 1999, 15, 363-367. [CrossRef]

62. Harada, N.; Nishiyama, M.; Otsuka, S.; Matsumoto, S. Effects of inoculation of phototrophic purple bacteria on grain yield of rice and nitrogenase activity of paddy soil in a pot experiment. Soil Sci. Plant Nutr. 2005, 51, 361-367. [CrossRef]

63. Yoshida, T.; Tabata, T.; Saraswati, R.; Kobayashi, M. Study on resourceful disposal of organic waste and high-yielding culture of rice plant. J. Environ. Conserv. Eng. 1991, 20, 607-610. [CrossRef]

64. Gamal-Eldin, H.; Elbanna, K. Field evidence for the potential of Rhodobacter capsulatus as Biofertilizer for flooded rice. Curr. Microbiol. 2011, 62, 391-395. [CrossRef]

65. Sakpirom, J.; Kantachote, D.; Nunkaew, T.; Khan, E. Characterizations of purple non-sulfur bacteria isolated from paddy fields, and identification of strains with potential for plant growth-promotion, greenhouse gas mitigation and heavy metal bioremediation. Res. Microbiol. 2017, 168, 266-275. [CrossRef] [PubMed]

66. Kantachote, D.; Nunkaew, T.; Kantha, T.; Chaiprapat, S. Biofertilizers from Rhodopseudomonas palustris strains to enhance rice yields and reduce methane emissions. Appl. Soil Ecol. 2016, 100, 154-161. [CrossRef]

67. Kantha, T.; Kantachote, D.; Klongdee, N. Potential of biofertilizers from selected Rhodopseudomonas palustris strains to assist rice (Oryza sativa L. subsp. indica) growth under salt stress and to reduce greenhouse gas emissions. Ann. Microbiol. 2015, 65, 2109-2118. [CrossRef]

68. Ge, H.; Liu, Z.; Zhang, F. Effect of Rhodopseudomonas palustris G5 on seedling growth and some physiological and biochemical characteristics of cucumber under cadmium stress. Emir. J. Food Agric. 2017, 29, 816. [CrossRef]

69. Ge, H.; Zhang, F. Growth-Promoting Ability of Rhodopseudomonas palustris G5 and its effect on induced resistance in cucumber against salt stress. J. Plant Growth Regul. 2019, 38, 180-188. [CrossRef]

70. Batool, K.; Tuz Zahra, F.; Rehman, Y. Arsenic-redox transformation and plant growth promotion by purple nonsulfur bacteria Rhodopseudomonas palustris CS2 and Rhodopseudomonas faecalis SS5. BioMed Res. Int. 2017, 2017, 6250327. [CrossRef] [PubMed]

71. Nookongbut, P.; Kantachote, D.; Megharaj, M. Arsenic contamination in areas surrounding mines and selection of potential As-resistant purple nonsulfur bacteria for use in bioremediation based on their detoxification mechanisms. Ann. Microbiol. 2016, 66, 1419-1429. [CrossRef]

72. Nookongbut, P.; Kantachote, D.; Megharaj, M.; Naidu, R. Reduction in arsenic toxicity and uptake in rice (Oryza sativa L.) by As-resistant purple nonsulfur bacteria. Environ. Sci. Pollut. Res. Int. 2018, 25, 36530-36544. [CrossRef] [PubMed]

73. Su, P.; Tan, X.; Li, C.; Zhang, D.; Cheng, J.E.; Zhang, S.; Zhou, X.; Yan, Q.; Peng, J.; Zhang, Z.; et al. Photosynthetic bacterium $R$ hodopseudomonas palustris GJ-22 induces systemic resistance against viruses. Microb. Biotechnol. 2017, 10, 612-624. [CrossRef] [PubMed]

74. Su, P.; Zhang, D.; Zhang, Z.; Chen, A.; Hamid, M.R.; Li, C.; Du, J.; Cheng, J.e.; Tan, X.; Zhen, L.; et al. Characterization of Rhodopseudomonas palustris population dynamics on tobacco phyllosphere and induction of plant resistance to Tobacco mosaic virus. Microb. Biotechnol. 2019, 12, 1453-1463. [CrossRef] [PubMed]

75. Yin, L.; Li, X.; Liu, Y.; Zhang, D.; Zhang, S.; Luo, X. Biodegradation of cypermethrin by Rhodopseudomonas palustris GJ-22 isolated from activated sludge. Fresen Env. Bull 2012, 21, 397-405.

76. Nookongbut, P.; Kantachote, D.; Khuong, N.Q.; Tantirungkij, M. The biocontrol potential of acid-resistant Rhodopseudomonas palustris KTSSR54 and its exopolymeric substances against rice fungal pathogens to enhance rice growth and yield. Biol. Control 2020, 150, 104354. [CrossRef] 
77. Nookongbut, P.; Kantachote, D.; Khuong, N.Q.; Sukhoom, A.; Tantirungkij, M.; Limtong, S. Selection of acid-resistant purple nonsulfur bacteria from peat swamp forests to apply as biofertilizers and biocontrol agents. J. Soil Sci. Plant Nutr. 2019, 19, 488-500. [CrossRef]

78. Kang, S.M.; Adhikari, A.; Lee, K.E.; Khan, M.A.; Shahzad, R.; Dhungana, S.K.; Lee, I.J. Inoculation with indole-3-acetic acidproducing rhizospheric Rhodobacter sphaeroides KE149 augments growth of adzuki bean plants under water stress. J. Microbiol. Biotechnol. 2020, 30, 717-725. [CrossRef] [PubMed]

79. Kang, S.-M.; Adhikari, A.; Khan, M.A.; Kwon, E.-H.; Park, Y.-S.; Lee, I.-J. Influence of the rhizobacterium Rhodobacter sphaeroides KE149 and biochar on waterlogging stress tolerance in Glycine max L. Environments 2021, 8, 94. [CrossRef]

80. Ahemad, M.; Kibret, M. Mechanisms and applications of plant growth promoting rhizobacteria: Current perspective. J. King Saud Univ. -Sci. 2014, 26, 1-20. [CrossRef]

81. Santi, C.; Bogusz, D.; Franche, C. Biological nitrogen fixation in non-legume plants. Ann. Bot. 2013, 111, 743-767. [CrossRef]

82. Rodrigo Omar, M.-T.; Porfirio, J.-L.; Ronald-Ernesto, O.-C.; Manuel, S.-V.; Iran, A.-T.; Gelacio, A.-S. Estimating nitrogen and chlorophyll status of romaine lettuce using SPAD and at LEAF readings. Not. Bot. Horti Agrobot. Cluj-Napoca 2019, 47, 751-756. [CrossRef]

83. Yang, G.; Wei, Q.; Huang, H.; Xia, J. Amino acid transporters in plant cells: A brief review. Plants 2020, 9, 967. [CrossRef] [PubMed]

84. Franche, C.; Lindström, K.; Elmerich, C. Nitrogen-fixing bacteria associated with leguminous and non-leguminous plants. Plant Soil 2009, 321, 35-59. [CrossRef]

85. Lam, H.M.; Coschigano, K.T.; Oliveira, I.C.; Melo-Oliveira, R.; Coruzzi, G.M. The molecular-genetics of nitrogen assimilation into amino acids in higher plants. Annu. Rev. Plant Physiol. Plant Mol. Biol. 1996, 47, 569-593. [CrossRef]

86. Norman, J.S.; Friesen, M.L. Complex N acquisition by soil diazotrophs: How the ability to release exoenzymes affects $\mathrm{N}$ fixation by terrestrial free-living diazotrophs. ISME J. 2017, 11, 315-326. [CrossRef]

87. Goswami, D.; Thakker, J.N.; Dhandhukia, P.C. Portraying mechanics of plant growth promoting rhizobacteria (PGPR): A review. Cogent Food Agric. 2016, 2, 1127500. [CrossRef]

88. Olivares, J.; Bedmar, E.J.; Sanjuán, J. Biological nitrogen fixation in the context of global change. Mol. Plant-Microbe Interact. 2013, 26, 486-494. [CrossRef]

89. Lo, K.-J.; Lin, S.-S.; Lu, C.-W.; Kuo, C.-H.; Liu, C.-T. Whole-genome sequencing and comparative analysis of two plant-associated strains of Rhodopseudomonas palustris (PS3 and YSC3). Sci. Rep. 2018, 8, 1-15.

90. Jiang, K.; Asami, T. Chemical regulators of plant hormones and their applications in basic research and agriculture*. Biosci. Biotechnol. Biochem. 2018, 82, 1265-1300. [CrossRef]

91. Wani, S.H.; Kumar, V.; Shriram, V.; Sah, S.K. Phytohormones and their metabolic engineering for abiotic stress tolerance in crop plants. Crop. J. 2016, 4, 162-176. [CrossRef]

92. Jacoby, R.; Peukert, M.; Succurro, A.; Koprivova, A.; Kopriva, S. The role of soil microorganisms in plant mineral nutrition-current knowledge and future directions. Front. Plant Sci. 2017, 8, 1617. [CrossRef]

93. Tsavkelova, E.A.; Klimova, S.Y.; Cherdyntseva, T.A.; Netrusov, A.I. Microbial producers of plant growth stimulators and their practical use: A review. Appl. Biochem. Microbiol. 2006, 42, 117-126. [CrossRef]

94. Bending, G.D.; Rodríguez-Cruz, M.S.; Lincoln, S.D. Fungicide impacts on microbial communities in soils with contrasting management histories. Chemosphere 2007, 69, 82-88. [CrossRef]

95. Kaymak, H.C. Potential of PGPR in Agricultural Innovations. In Plant Growth and Health Promoting Bacteria; Maheshwari, D.K., Ed.; Springer: Berlin/Heidelberg, Germany, 2011; pp. 45-79.

96. Vessey, J.K. Plant growth promoting rhizobacteria as biofertilizers. Plant Soil 2003, 255, 571-586. [CrossRef]

97. Spaepen, S.; Vanderleyden, J. Auxin and plant-microbe interactions. Cold Spring Harb Perspect. Biol. 2011, 3, a001438. [CrossRef] [PubMed]

98. Zhang, P.; Jin, T.; Kumar Sahu, S.; Xu, J.; Shi, Q.; Liu, H.; Wang, Y. The distribution of tryptophan-dependent indole-3-acetic acid synthesis pathways in bacteria unraveled by large-scale genomic analysis. Molecules 2019, 24, 1411. [CrossRef] [PubMed]

99. Spaepen, S.; Vanderleyden, J.; Remans, R. Indole-3-acetic acid in microbial and microorganism-plant signaling. FEMS Microbiol. Rev. 2007, 31, 425-448. [CrossRef] [PubMed]

100. Mariana, U.B.; Hernández-Mendoza, J.; Armando, G.C.; Veronica, A.; Larios-Serrato, V. Independent tryptophan pathway in Trichoderma asperellum and T koningiopsis: New insights with bioinformatic and molecular analysis. bioRxiv 2020. [CrossRef]

101. Koh, R.H.; Song, H.G. Effects of application of Rhodopseudomonas sp. on seed germination and growth of tomato under axenic conditions. J. Microbiol. Biotechnol. 2007, 17, 1805-1810.

102. Nookongbut, P.; Jingjit, N.; Kantachote, D.; Sukhoom, A.; Tantirungkij, M. Selection of acid tolerant purple nonsulfur bacteria for application in agriculture. Chiang Mai Univ. J. Nat. Sci. 2020, 19, 775. [CrossRef]

103. Bong, K.; Kim, J.; Yoo, J.-H.; Park, I.; Lee, C.W.; Kim, P. Mass Cultivation and secondary metabolite analysis of Rhodobacter capsulatus PS-2. KSBB J. 2016, 31, 158-164. [CrossRef]

104. González-Fontes, A.; Navarro-Gochicoa, M.T.; Ceacero, C.J.; Herrera-Rodríguez, M.B.; Camacho-Cristóbal, J.J.; Rexach, J. Understanding calcium transport and signaling, and its use efficiency in vascular plants. In Plant Macronutrient Use Efficiency; Hossain, M.A., Kamiya, T., Burritt, D.J., Tran, L.-S.P., Fujiwara, T., Eds.; Academic Press: Cambridge, MA, USA, 2017 ; pp. 165-180.

105. Baligar, V.; Fageria, N.; He, Z. Nutrient use efficiency in plants. Commun. Soil Sci. Plant Anal. 2001, 32, 921-950. [CrossRef] 
106. Reich, M.; Aghajanzadeh, T.; De Kok, L.J. Physiological basis of plant nutrient use efficiency-concepts, opportunities and challenges for its improvement. In Nutrient Use Efficiency in Plants; Springer: Berlin/Heidelberg, Germany, $2014 ;$ pp. 1-27.

107. Blom-Zandstra, M. Nitrate accumulation in vegetables and its relationship to quality. Ann. Appl. Biol. 1989, 115, 553-561. [CrossRef]

108. Steingröver, E.G.; Ratering, P.; Siesling, J. Daily changes in uptake, reduction and storage of nitrate in spinach grown at low light intensity. Physiol. Plant. 2006, 66, 550-556. [CrossRef]

109. Du, S.-t.; Zhang, Y.-s.; Lin, X. Accumulation of nitrate in vegetables and its possible implications to human health. Agric. Sci. China 2007, 6, 1246-1255. [CrossRef]

110. Wang, W.; Vinocur, B.; Altman, A. Plant responses to drought, salinity and extreme temperatures: Towards genetic engineering for stress tolerance. Planta 2003, 218, 1-14. [CrossRef] [PubMed]

111. Rouphael, Y.; Kyriacou, M.C.; Colla, G. Vegetable grafting: A toolbox for securing yield stability under multiple stress conditions. Front. Plant Sci. 2018, 8, 2255. [CrossRef]

112. Rouphael, Y.; Kyriacou, M.C.; Petropoulos, S.A.; De Pascale, S.; Colla, G. Improving vegetable quality in controlled environments. Sci. Hortic. 2018, 234, 275-289. [CrossRef]

113. Liu, X.X.; Wang, L.; Wang, Y.J.; Cai, L.L. D-glucose enhanced 5-aminolevulinic acid production in recombinant Escherichia coli culture. Appl. Biochem. Biotechnol. 2010, 160, 822-830. [CrossRef] [PubMed]

114. Naeem, M.; Jin, Z.; Wan, G.; Liu, D.; Liu, H.; Yoneyama, K.; Zhou, W. 5-Aminolevulinic acid improves photosynthetic gas exchange capacity and ion uptake under salinity stress in oilseed rape (Brassica napus L.). Plant Soil 2010, 332, 405-415. [CrossRef]

115. Xiong, J.-L.; Wang, H.-C.; Tan, X.-Y.; Zhang, C.-L.; Naeem, M.S. 5-aminolevulinic acid improves salt tolerance mediated by regulation of tetrapyrrole and proline metabolism in Brassica napus L. seedlings under $\mathrm{NaCl}$ stress. Plant Physiol. Biochem. 2018, 124, 88-99. [CrossRef]

116. Liu, S.; Zhang, G.; Li, X.; Zhang, J. Microbial production and applications of 5-aminolevulinic acid. Appl. Microbiol. Biotechnol. 2014, 98, 7349-7357. [CrossRef] [PubMed]

117. Kantha, T.; Chaiyasut, C.; Kantachote, D.; Sukrong, S.; Muangprom, A. Selection of photosynthetic bacteria producing 5aminolevulinic acid from soil of organic saline paddy fields from the Northeast region of Thailand. Afr. J. Microbiol. Res. 2010, 4, 1848-1855.

118. Nunkaew, T.; Kantachote, D.; Kanzaki, H.; Nitoda, T.; Ritchie, R.J. Effects of 5-aminolevulinic acid (ALA)-containing supernatants from selected Rhodopseudomonas palustris strains on rice growth under $\mathrm{NaCl}$ stress, with mediating effects on chlorophyll, photosynthetic electron transport and antioxidative enzymes. Electron. J. Biotechnol. 2014, 17, 4. [CrossRef]

119. Saikeur, A.; Choorit, W.; Prasertsan, P.; Kantachote, D.; Sasaki, K. Influence of precursors and inhibitor on the production of extracellular 5-aminolevulinic acid and biomass by Rhodopseudomonas palustris KG31. Biosci. Biotechnol. Biochem. 2009, 73, 987-992. [CrossRef] [PubMed]

120. Rebeiz, C.A.; Montazer-Zouhoor, A.; Hopen, H.J.; Wu, S.M. Photodynamic herbicides: 1. Concept and phenomenology. Enzym. Microb. Technol. 1984, 6, 390-396. [CrossRef]

121. Sasaki, K.; Watanabe, M.; Tanaka, T.; Tanaka, T. Biosynthesis, biotechnological production and applications of 5-aminolevulinic acid. Appl. Microbiol. Biotechnol. 2002, 58, 23-29. [CrossRef]

122. Cardoso, E.; Vasconcellos, R.; Bini, D.; Miyauchi, M.; Alcantara, C.; Alves, P.; de Paula, A.; Nakatani, A.; Pereira, J.; Nogueira, M. Soil health: Looking for suitable indicators. What should be considered to assess the effects of use and management on soil health? Sci. Agric. 2013, 70, 219-303. [CrossRef]

123. Lugtenberg, B.; Kamilova, F. Plant-Growth-Promoting Rhizobacteria. Annu. Rev. Microbiol. 2009, 63, 541-556. [CrossRef] [PubMed]

124. Ezeokoli, O.T.; Bezuidenhout, C.C.; Maboeta, M.S.; Khasa, D.P.; Adeleke, R.A. Structural and functional differentiation of bacterial communities in post-coal mining reclamation soils of South Africa: Bioindicators of soil ecosystem restoration. Sci. Rep. 2020, 10, 1759. [CrossRef]

125. Rosenstock, B.; Simon, M. Consumption of dissolved amino acids and carbohydrates by limnetic bacterioplankton according to molecular weight fractions and proportions bound to humic matter. Microb. Ecol. 2003, 45, 433-443. [CrossRef]

126. Liu, L.; Zhang, T.; Gilliam, F.S.; Gundersen, P.; Zhang, W.; Chen, H.; Mo, J. Interactive effects of nitrogen and phosphorus on soil microbial communities in a tropical forest. PLoS ONE 2013, 8, e61188. [CrossRef] [PubMed]

127. Sahu, P.K.; Singh, D.P.; Prabha, R.; Meena, K.K.; Abhilash, P.C. Connecting microbial capabilities with the soil and plant health: Options for agricultural sustainability. Ecol. Indic. 2019, 105, 601-612. [CrossRef]

128. Yang, M.; Yang, D.; Yu, X. Soil microbial communities and enzyme activities in sea-buckthorn (Hippophae rhamnoides) plantation at different ages. PLoS ONE 2018, 13, e0190959. [CrossRef] [PubMed]

129. Cai, F.; Pang, G.; Miao, Y.; Li, R.; Shen, Q.; Chen, W. The nutrient preference of plants influences their rhizosphere microbiome. Appl. Soil Ecol. 2017, 110, 146-150. [CrossRef]

130. Ofek, M.; Voronov-Goldman, M.; Hadar, Y.; Minz, D. Host signature effect on plant root-associated microbiomes revealed through analyses of resident vs. active communities. Environ. Microbiol. 2014, 16, 2157-2167. [CrossRef] [PubMed]

131. Xun, W.; Huang, T.; Zhao, J.; Ran, W.; Wang, B.; Shen, Q.; Zhang, R. Environmental conditions rather than microbial inoculum composition determine the bacterial composition, microbial biomass and enzymatic activity of reconstructed soil microbial communities. Soil Biol. Biochem. 2015, 90, 10-18. [CrossRef] 
132. Kang, Y.; Shen, M.; Wang, H.; Zhao, Q. A possible mechanism of action of plant growth-promoting rhizobacteria (PGPR) strain Bacillus pumilus WP8 via regulation of soil bacterial community structure. J. Gen. Appl. Microbiol. 2013, 59, 267-277. [CrossRef]

133. Bai, Y.-C.; Chang, Y.-Y.; Hussain, M.; Lu, B.; Zhang, J.-P.; Song, X.-B.; Lei, X.-S.; Pei, D. Soil Chemical and microbiological properties are changed by long-term chemical fertilizers that limit ecosystem functioning. Microorganisms 2020, 8, 694. [CrossRef] [PubMed]

134. Wang, Y.; Peng, S.; Hua, Q.; Qiu, C.; Wu, P.; Liu, X.; Lin, X. The long-term effects of using phosphate-solubilizing bacteria and photosynthetic bacteria as biofertilizers on peanut yield and soil bacteria community. Front. Microbiol. 2021, 12. [CrossRef]

135. Navarrete, A.A.; Soares, T.; Rossetto, R.; van Veen, J.A.; Tsai, S.M.; Kuramae, E.E. Verrucomicrobial community structure and abundance as indicators for changes in chemical factors linked to soil fertility. Antonie Van Leeuwenhoek 2015, 108, 741-752. [CrossRef] [PubMed]

136. Flint, M.L.; Dreistadt, S.H. Dreistadt. Natural Enemies Handbook: The Illustrated Guide to Biological Pest Control; Clark, J.K., Ed.; University of California Press: Oakland, CA, USA, 1998.

137. Savary, S.; Nelson, A.; Sparks, A.H.; Willocquet, L.; Duveiller, E.; Mahuku, G.; Forbes, G.; Garrett, K.A.; Hodson, D.; Padgham, J. International agricultural research tackling the effects of global and climate changes on plant diseases in the developing world. Plant Dis. 2011, 95, 1204-1216. [CrossRef] [PubMed]

138. Heimpel, G.E.; Mills, N.J. Biological Control: Ecology and Applications; Cambridge University Press: Cambridge, UK, 2017; pp. 1-380.

139. Choudhary, D.K.; Prakash, A.; Johri, B.N. Induced systemic resistance (ISR) in plants: Mechanism of action. Indian J. Microbiol. 2007, 47, 289-297. [CrossRef] [PubMed]

140. Jiao, X.; Takishita, Y.; Zhou, G.; Smith, D.L. Plant associated rhizobacteria for biocontrol and plant growth enhancement. Front. Plant Sci. 2021, 12, 634796. [CrossRef]

141. Zhai, Z.; Chen, A.; Zhou, H.; Zhang, D.; Du, X.; Liu, Q.; Wu, X.; Cheng, J.; Chen, L.; Hu, F.; et al. Structural characterization and functional activity of an exopolysaccharide secreted by Rhodopseudomonas palustris GJ-22. Int. J. Biol. Macromol. 2021, 167, 160-168. [CrossRef]

142. Souza, R.; Ambrosini, A.; Passaglia, L.M. Plant growth-promoting bacteria as inoculants in agricultural soils. Genet. Mol. Biol. 2015, 38, 401-419. [CrossRef] [PubMed]

143. Cardinale, M.; Ratering, S.; Suarez, C.; Zapata Montoya, A.M.; Geissler-Plaum, R.; Schnell, S. Paradox of plant growth promotion potential of rhizobacteria and their actual promotion effect on growth of barley (Hordeum vulgare L.) under salt stress. Microbiol. Res. 2015, 181, 22-32. [CrossRef]

144. Bonatelli, M.L.; Lacerda-Júnior, G.V.; dos Reis Junior, F.B.; Fernandes-Júnior, P.I.; Melo, I.S.; Quecine, M.C. Beneficial plantassociated microorganisms from semiarid regions and seasonally dry environments: A review. Front. Microbiol. $2021,11$. [CrossRef]

145. Mitter, E.K.; Tosi, M.; Obregón, D.; Dunfield, K.E.; Germida, J.J. Rethinking crop nutrition in times of modern microbiology: Innovative biofertilizer technologies. Front. Sustain. Food Syst. 2021, 5, 29. [CrossRef]

146. Vacheron, J.; Desbrosses, G.; Bouffaud, M.L.; Touraine, B.; Moënne-Loccoz, Y.; Muller, D.; Legendre, L.; Wisniewski-Dyé, F.; Prigent-Combaret, C. Plant growth-promoting rhizobacteria and root system functioning. Front. Plant Sci. 2013, 4, 356. [CrossRef] [PubMed]

147. Santoyo, G.; Guzmán-Guzmán, P.; Parra-Cota, F.I.; Santos-Villalobos, S.D.L.; Orozco-Mosqueda, M.; Glick, B.R. Plant Growth Stimulation by Microbial Consortia. Agronomy 2021, 11, 219. [CrossRef]

148. Compant, S.; Samad, A.; Faist, H.; Sessitsch, A. A review on the plant microbiome: Ecology, functions, and emerging trends in microbial application. J. Adv. Res. 2019, 19, 29-37. [CrossRef] [PubMed]

149. O'Callaghan, M. Microbial inoculation of seed for improved crop performance: Issues and opportunities. Appl. Microbiol. Biotechnol. 2016, 100, 5729-5746. [CrossRef]

150. Potts, M. Desiccation tolerance of prokaryotes. Microbiol. Rev. 1994, 58, 755-805. [CrossRef]

151. Berninger, T.; González López, Ó.; Bejarano, A.; Preininger, C.; Sessitsch, A. Maintenance and assessment of cell viability in formulation of non-sporulating bacterial inoculants. Microb. Biotechnol. 2018, 11, 277-301. [CrossRef]

152. Kumaresan, G.; Reetha, D. Survival of Azospirillum brasilense in liquid formulation amended with different chemical additives. J. Phytol. 2011, 3, 48-51.

153. Anith, K.; Vaishakhi, A.; Viswanathan, A.; Varkey, S.; Aswini, S. Population dynamics and efficiency of coconut water based liquid formulation of Pseudomonas fluorescens AMB-8. J. Trop. Agric. 2017, 54, 184.

154. Bernabeu, P.R.; García, S.S.; López, A.C.; Vio, S.A.; Carrasco, N.; Boiardi, J.L.; Luna, M.F. Assessment of bacterial inoculant formulated with Paraburkholderia tropica to enhance wheat productivity. World J. Microbiol. Biotechnol. 2018, 34, 81. [CrossRef]

155. Lee, S.K.; Lur, H.S.; Lo, K.J.; Cheng, K.C.; Chuang, C.C.; Tang, S.J.; Yang, Z.W.; Liu, C.T. Evaluation of the effects of different liquid inoculant formulations on the survival and plant-growth-promoting efficiency of Rhodopseudomonas palustris strain PS3. Appl. Microbiol. Biotechnol. 2016, 100, 7977-7987. [CrossRef] [PubMed]

156. Pastor-Bueis, R.; Mulas, R.; Gómez, X.; González-Andrés, F. Innovative liquid formulation of digestates for producing a biofertilizer based on Bacillus siamensis: Field testing on sweet pepper. J. Plant Nutr. Soil Sci. 2017, 180, 748-758. [CrossRef]

157. Valetti, L.; Angelini, J.; Taurian, T.; Ibañez, F.; Muñoz, V.; Anzuay, S.; Ludueña, L.; Fabra, A. Development and field evaluation of liquid inoculants with native Bradyrhizobial strains for peanut production. Afr. Crop. Sci. J. 2016, 24, 1. [CrossRef] 
158. Lobo, C.B.; Juárez Tomás, M.S.; Viruel, E.; Ferrero, M.A.; Lucca, M.E. Development of low-cost formulations of plant growthpromoting bacteria to be used as inoculants in beneficial agricultural technologies. Microbiol. Res. 2019, 219, 12-25. [CrossRef] [PubMed]

159. Berger, B.; Patz, S.; Ruppel, S.; Dietel, K.; Faetke, S.; Junge, H.; Becker, M. Successful formulation and application of plant growth-promoting Kosakonia radicincitans in maize cultivation. BioMed Res. Int. 2018, 2018, 6439481. [CrossRef]

160. He, Y.; Peng, Y.; Han, Y.; Dang, Y. Survivability of Pseudomonas putida Rs-198 in liquid formulations and evaluation its growthpromoting abilities on cotton. J. Anim. Plant Sci. 2015, 25, 180-189.

161. Kari, A.; Nagymáté, Z.; Romsics, C.; Vajna, B.; Tóth, E.; Lazanyi-Kovács, R.; Rizó, B.; Kutasi, J.; Bernhardt, B.; Farkas, É.; et al. Evaluating the combined effect of biochar and PGPR inoculants on the bacterial community in acidic sandy soil. Appl. Soil Ecol. 2021, 160, 103856. [CrossRef]

162. Ding, Y.; Liu, Y.; Liu, S.; Li, Z.; Tan, X.; Huang, X.; Zeng, G.; Zhou, L.; Zheng, B. Biochar to improve soil fertility. A review. Agron. Sustain. Dev. 2016, 36, 36. [CrossRef]

163. Hale, L.; Luth, M.; Crowley, D. Biochar characteristics relate to its utility as an alternative soil inoculum carrier to peat and vermiculite. Soil Biol. Biochem. 2015, 81, 228-235. [CrossRef]

164. Schoebitz, M.; López, M.D.; Roldán, A. Bioencapsulation of microbial inoculants for better soil-plant fertilization. A review. Agron. Sustain. Dev. 2013, 33, 751-765. [CrossRef]

165. Sim, D.H.H.; Tan, I.A.W.; Lim, L.L.P.; Hameed, B.H. Encapsulated biochar-based sustained release fertilizer for precision agriculture: A review. J. Clean. Prod. 2021, 303, 127018. [CrossRef]

166. Vanek, S.; Thies, J. Pore-Size and Water Activity Effects on Survival of Rhizobium tropici in Biochar Inoculant Carriers. J. Microb. Biochem. Technol. 2016, 8, 296-306. [CrossRef]

167. Hussain, M.; Farooq, M.; Nawaz, A.; Al-Sadi, A.M.; Solaiman, Z.M.; Alghamdi, S.S.; Ammara, U.; Ok, Y.S.; Siddique, K.H.M Biochar for crop production: Potential benefits and risks. J. Soils Sediments 2017, 17, 685-716. [CrossRef]

168. Jiménez-Gómez, A.; Celador-Lera, L.; Fradejas-Bayón, M.; Rivas, R. Plant probiotic bacteria enhance the quality of fruit and horticultural crops. AIMS Microbiol. 2017, 3, 483-501. [CrossRef]

169. Sharma, A.; Shankhdhar, D.; Shankhdhar, S. Enhancing grain iron content of rice by the application of plant growth promoting rhizobacteria. Plant Soil Environ. 2013, 59, 89. [CrossRef]

170. Yildirim, E.; Karlidag, H.; Turan, M.; Dursun, A.; Goktepe, F. Growth, nutrient uptake, and yield promotion of broccoli by plant growth promoting rhizobacteria with manure. HortScience 2011, 46, 932-936. [CrossRef]

171. Blekkenhorst, L.C.; Sim, M.; Bondonno, C.P.; Bondonno, N.P.; Ward, N.C.; Prince, R.L.; Devine, A.; Lewis, J.R.; Hodgson, J.M Cardiovascular health benefits of specific vegetable types: A narrative review. Nutrients 2018, 10, 595. [CrossRef] [PubMed]

172. Mishra, G.D.; Schoenaker, D.A.; Mihrshahi, S.; Dobson, A.J. How do women's diets compare with the new Australian dietary guidelines? Public Health Nutr. 2015, 18, 218-225. [CrossRef]

173. World Health Organization. Fruit and Vegetables for Health: Report of the Joint FAO. 2005. Available online: https://www.fao. org/3/y5861e/y5861e.pdf (accessed on 26 November 2021).

174. Martín León, V.; Luzardo, O.P. Evaluation of nitrate contents in regulated and non-regulated leafy vegetables of high consumption in the Canary Islands, Spain: Risk assessment. Food Chem. Toxicol. 2020, 146, 111812. [CrossRef] [PubMed]

175. Santamaria, P. Nitrate in vegetables: Toxicity, content, intake and EC regulation. J. Sci. Food Agric. 2006, 86, 10-17. [CrossRef]

176. Luo, J.; Sun, S.; Jia, L.; Chen, W.; Shen, Q. The mechanism of nitrate accumulation in Pakchoi [Brassica Campestris L.ssp. Chinensis(L.)]. Plant Soil 2006, 282, 291-300. [CrossRef]

177. Bacanli, M.; Başaran, N.; Başaran, A.A. Lycopene: Is it beneficial to human health as an antioxidant? Turk. J. Pharm. Sci. 2017, 14, 311-318. [CrossRef] [PubMed]

178. Lee, E.R.; Kang, G.H.; Cho, S.G. Effect of flavonoids on human health: Old subjects but new challenges. Recent Pat. Biotechnol. 2007, 1, 139-150. [CrossRef]

179. Ajami, M.; Seyfi, M.; Abdollah Pouri Hosseini, F.; Naseri, P.; Velayati, A.; Mahmoudnia, F.; Zahedirad, M.; Hajifaraji, M. Effects of stevia on glycemic and lipid profile of type 2 diabetic patients: A randomized controlled trial. Avicenna J. Phytomedicine 2020, 10, 118-127.

180. Bundgaard Anker, C.C.; Rafiq, S.; Jeppesen, P.B. Effect of Steviol Glycosides on Human Health with Emphasis on Type 2 Diabetic Biomarkers: A Systematic Review and Meta-Analysis of Randomized Controlled Trials. Nutrients 2019, 11, 1965. [CrossRef]

181. Harada, N.; Otsuka, S.; Nishiyama, M.; Matsumoto, S. Characteristics of phototrophic purple bacteria isolated from a Japanese paddy soil. Soil Sci. Plant Nutr. 2003, 49, 521-526. [CrossRef]

182. Giomi, T.; Runhaar, P.; Runhaar, H. Reducing agrochemical use for nature conservation by Italian olive farmers: An evaluation of public and private governance strategies. Int. J. Agric. Sustain. 2018, 16, 94-105. [CrossRef]

183. Mendes, R.; Garbeva, P.; Raaijmakers, J.M. The rhizosphere microbiome: Significance of plant beneficial, plant pathogenic, and human pathogenic microorganisms. FEMS Microbiol. Rev. 2013, 37, 634-663. [CrossRef]

184. More, S.S.; Shinde, S.E.; Kasture, M.C. Root exudates a key factor for soil and plant: An overview. Pharma Innov. J. 2020, 8, 449-459.

185. Ali, B.; Sabri, A.N.; Ljung, K.; Hasnain, S. Auxin production by plant associated bacteria: Impact on endogenous IAA content and growth of Triticum aestivum L. Lett. Appl. Microbiol. 2009, 48, 542-547. [CrossRef] [PubMed]

186. Mehmood, A.; Hussain, A.; Irshad, M.; Hamayun, M.; Iqbal, A.; Khan, N. In vitro production of IAA by endophytic fungus Aspergillus awamori and its growth promoting activities in Zea mays. Symbiosis 2019, 77, 225-235. [CrossRef] 
187. Lo, K.J.; Lee, S.K.; Liu, C.T. Development of a low-cost culture medium for the rapid production of plant growth-promoting Rhodopseudomonas palustris strain PS3. PLoS ONE 2020, 15, e0236739. [CrossRef] [PubMed]

188. Burges, H.D. Formulation of Microbial Biopesticides: Beneficial Microorganisms, Nematodes and Seed Treatments; Springer Science \& Business Media: Dordrecht, The Netherlands, 2012.

189. Stephens, J.H.G.; Rask, H.M. Inoculant production and formulation. Field Crop. Res. 2000, 65, 249-258. [CrossRef]

190. Bashan, Y.; de-Bashan, L.E.; Prabhu, S.R.; Hernandez, J.-P. Advances in plant growth-promoting bacterial inoculant technology: Formulations and practical perspectives (1998-2013). Plant Soil 2014, 378, 1-33. [CrossRef]

191. Dayamani, K.J.; Brahmaprakash, P.G. Influence of form and concentration of the osmolytes in liquid inoculants formulations of plant growth promoting bacteria. Int. J. Sci. Res. Publ. 2014, 4, 449-454.

192. Gomez, M.; Silva, N.; Hartmann, A.; Sagardoy, M.; Catroux, G. Evaluation of commercial soybean inoculants from Argentina. World J. Microbiol. Biotechnol. 1997, 13, 167-173. [CrossRef]

193. Gouda, S.; Kerry, R.G.; Das, G.; Paramithiotis, S.; Shin, H.S.; Patra, J.K. Revitalization of plant growth promoting rhizobacteria for sustainable development in agriculture. Microbiol. Res. 2018, 206, 131-140. [CrossRef] [PubMed]

194. Santos, M.S.; Nogueira, M.A.; Hungria, M. Microbial inoculants: Reviewing the past, discussing the present and previewing an outstanding future for the use of beneficial bacteria in agriculture. AMB Express 2019, 9, 205. [CrossRef]

195. Timmusk, S.; Behers, L.; Muthoni, J.; Muraya, A.; Aronsson, A.-C. Perspectives and Challenges of Microbial Application for Crop Improvement. Front. Plant Sci. 2017, 8, 49. [CrossRef] [PubMed] 